Portland State University

PDXScholar

7-1-1976

\title{
The Nature and Distribution of Turf-banked Terraces in the Olympic Mountains, Washington
}

Katherine Jane Hansen

Portland State University

Follow this and additional works at: https://pdxscholar.library.pdx.edu/open_access_etds

Part of the Physical and Environmental Geography Commons

Let us know how access to this document benefits you.

\section{Recommended Citation}

Hansen, Katherine Jane, "The Nature and Distribution of Turf-banked Terraces in the Olympic Mountains, Washington" (1976). Dissertations and Theses. Paper 5400.

https://doi.org/10.15760/etd.7273

This Thesis is brought to you for free and open access. It has been accepted for inclusion in Dissertations and Theses by an authorized administrator of PDXScholar. Please contact us if we can make this document more accessible: pdxscholar@pdx.edu. 
AN ABSTRACT OF THE THESIS OF Katherine Jane Hansen for the Master of Arts in Geography presented July 1, 1976.

Title: The Nature and Distribution of Turf-banked Terraces in the Olympic Mountains, Washington.

APPROVED BY MEMBERS OF THE THESIS COMMITTEE:

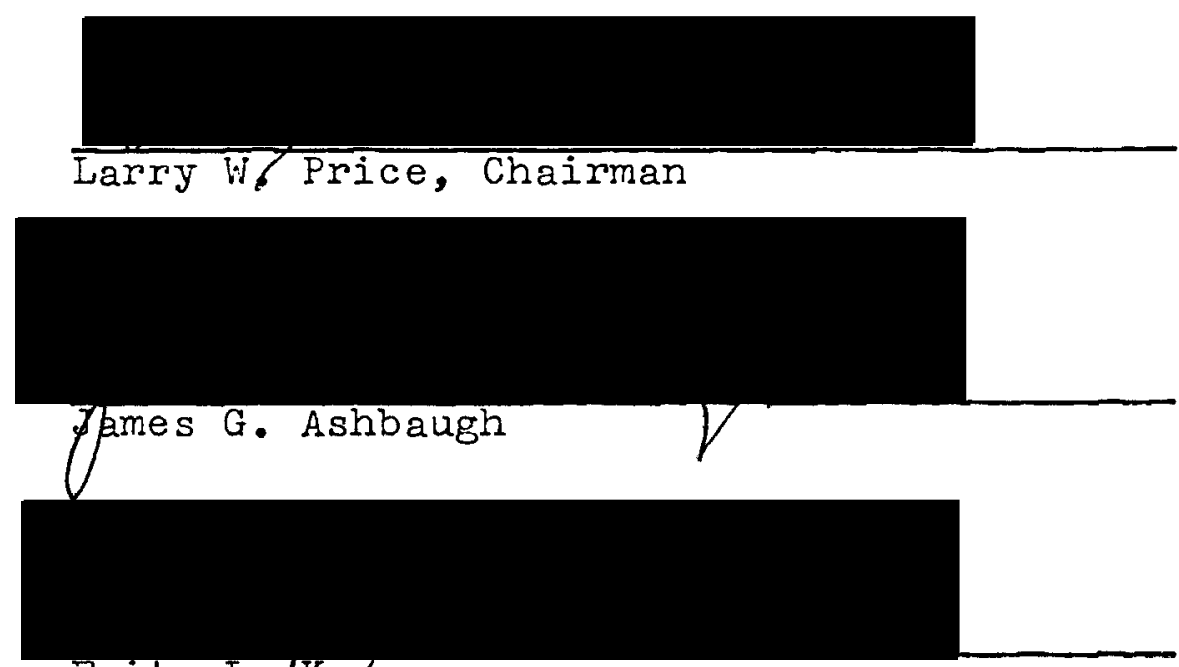

Fritz L. Kramer

Well-developed turf-banked terraces are found in the Olympic Mountains of Washington, but not found in the other mountains of the Pacific Northwest. My study is based just on the oiympic Mountains and the major thrust of my investigation is aimed at answering questions: What is the nature of turf-banked terrace development in the Olympic Mountains? Why does it occur, and what is its 
local ecological significance? The major field investigations were carried out during the summer of 1975.

A two hour reconnaissance was made over the Olympic Mountains to plot the distribution of turf-banked terraces; the most striking discovery was that terraces are limited to only a small area on the northeast side of the Olympics. Field measurements were made of slope orientation, slope angle, height. of risers, and length of treads. Vegetation transects were run across the terraces in order to ascertain ecological significance.' Internal characteristics of the terraces were investigated by making excavations through three representative terraces. Soil samples were collected and laboratory tested for texture analysis.

Turf-banized terraces occur in the Pacific Northwest only where the climate is of the continental-type and there are numerous freeze-thaw cycles, not where excessive moisture provides a mild, maritime climate. Terraces develop only on soil derived from sedimentary rock which has $a$ high rate of decomposition and breaks into fine material and not on the coarse soils derived from basalt or granite which have a slow rate of decomposition. Within the Olympic Mountains, turf-banked terraces occur only in a small area in the northeast section which has a relatively dry continental climate. They do not occur in other areas of the Olympic Mountains which 
are vory moist and have a maritime climate.

Within their arsa of occurrence, torraces devolop on north-facing slopes which are protected from southwesterly winds and whero soil is present. Terraces are found on the gentle, rounged alpine slopes, not exceeding $24_{4}^{\circ}$ and not less than $12^{\circ}$, where only occasional outcrops of bedrock are found. These rounded ridges have apparently. not been glaciated but have undergone cryoplanation over a long period of time. Terraces do not occur on southfacing slopes, which are generally steep and have little soil development. Terraces are not found on the steep. jagged cirque heads nor on the active cirque walls.

Terraces are well-developed on north-facing slopes immediately below late-lying snowbanks, which provide moisture that saturates the soil during spring meiting. Alpine vegetation with fine, thickly-matted roots covers the north-facing slopes, binding the soil, and the organic material assists the sandy loam in retaining water. Terraces do not develop in the olympics on unvegetated slopes.

Animals frequent the terraces and cause downslope movement when the soil is saturated. Grazing removes vegetation and promotes frost activity in the soil. Hikers crossing the terraces crush and uproot flowers and stems, 
but the concentration of traffic on trails is better than being dispersed use since it limits the damage. Movement takes place during spring when a frozen layer in the soil prohibits downward percolation of meltwater from late-lying snowbanks. Higher velocities in the center of the lobe results in the typical lobate appearance of the terraces.

It is hypothesized that terrace development began between 2500 and 3000 years B.P. The terraces appear active today. Hummocky treads, bulging risers, collapsed lobes give evidence of movement. 


\title{
THE NATURE AND DISTRIBUTION OF TURF-BANKED \\ TERRACES IN THE \\ OLYMPIC MOUNTAINS, WASHINGTON
}

by

KATHERINE JANE HANSEN

A thesis submitted in partial fulfillment of the requirements for the degree of

\author{
MASTER OF ARTS \\ in \\ GEOGRAPHY
}

\author{
Portland State University \\ 1976
}


TO THE OFFICE OF GRADUATE STUDIES AND RESEARCH:

The members of the Committee approve the thesis of Katherine Jane Hansen presented JuIy 1, 1976.

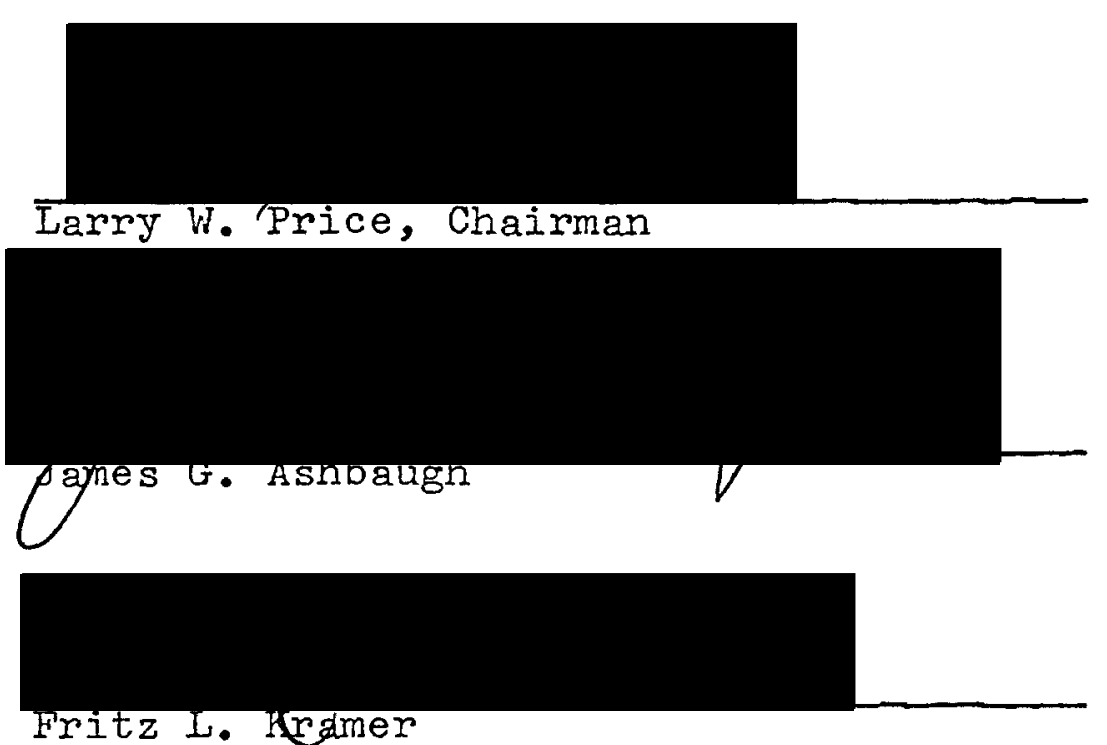

APPROVED :
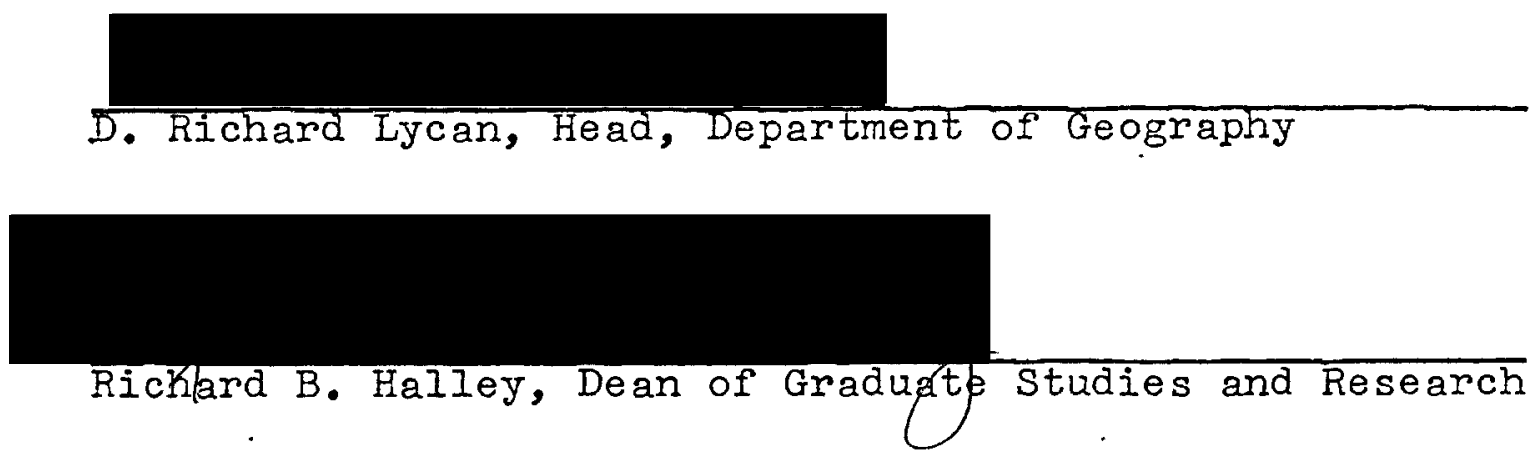


\section{ACKNOWLEDGMENTS}

I wish to take this time and space to tring. those who made my atudy in the Olympjc Mourtadns and the writing of this thesis possible.

I am most thacksul to Dr. Larry Price riho not only opened tre field of alpine study to me, but also imparted to me knowledge, perception, and enthusiasm for mountains.

My field work could not have been accomplisined without my faithful and enduring assistant and friend, Barbara Kennedy, who climbed the steep ridges and sat calmly with me for days in our wet tent. Paxt o? this thesis belongs to Barbara..

I am indebted to Mr. and Mrs. Bob Kelty of the Chympic National Park, who offered us their wam, dxy cajin and a hot meal when the weather was unbearabie.

I want to thank the Mazama Mountaineering Club of Portland for funding my study, the Olympic Nationel Paxis stafl who wexe always eager to help, and, of course, the entire Geography Depertment of Portland State University who gave me encowragement and friendship,

Thank you. 
TABLE OF CONTENTS

PAGE

ACKNOWLEDGMENTS . . . . . . . . . . . i ii

LIST OF TABLES . • • • • • • . • • • • • • • vi vi

LIST OF FIGURES . . . . . . . . . . . . vii vi

CHAPTER

I INTRODUCTION

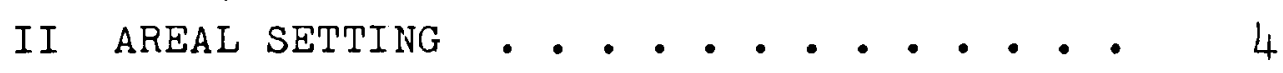

I. Geology ......... 4

II. Glaciation . . . . . . 9

III. Climate......... . 12

IV. Soils.......... 14

V. Vegetation ....... . 17

III DESCRIPTION OF STUDY SITES • • • • • • 20

IV NETHODS OF FIELD INVESTIGATION • • • • 31

$\mathrm{V}$ TERRACE DISTRIBUTION AND DESCRIPTION • • 33

Vi Vegetation . . . . . . . . . . . 40

I. Vegetation Communities ... 43

II. Snowbank Community . . . . 44

III. Tread Community ...... 45

IV. Riser Community . . . . . 47

VII LOBE EXCAVATIONS ....... . . 50

I. Lobe \#3......... . 50

II. Lobe \#10 . . . . . . . . 53

III. Lobe $\# 15$. . . . . . . 55 
VIII SOILS . . . . . . . . . . . . • 58

1. Soil Description . . . . . 58

II. Laboratory Tests . . . . . 60

III. Soil Formation ........ . 63

IX SOIL MOVBMENT MEASUREMENTS " • • . . . • 64

$X$ FACTORS INFLUENCING THE DISTRIBUTION AND

DEVELOPMENT OF TURF-BANKED TERRACES 68

XI CONCLUSION •. • • • • • • • • • 75 


\section{LIST OF TABLES}

TABLE

PAGE

I Microenvironmental data for two alpine

stations of the Olympic Mountains 15

II Riser Heights and Tread Lengths . . . 35

III Species and Their Relative and Total

Importance Values . ..... 42

IV Textural Analysis of Soils from

Turf-Banked Terraces . . . . 62 
LIST OF FIGURES.

FIGURE

PAGE

1. Turf-banked terraces and component Parts . . . . . . . . .

2. Major rivers and lakes of the Olympic

Peninsula

3. Predominant geologic features of the

Olympic Mountains . . . . .

4. Development of the Olympic Mountains.

5. U-Shaped valleys transect the Sedimentary Ridges : . . . . . . . .

6. A theoretical surface connecting small modern glaciers and a surface connecting pleistocene cirque floors ............

7. Precipitation in Millimeters for the Olympic Mountains . . . . .

8. Location of turf-banked terraces in the Olympic Mountains...... .

9. Terrace location at Maiden Peak . . 22

10. Terrace location at Gray Wolf cirque - 24

11. Terraces flow at an angle to the slope

on the northeast-facing slope at Maiden Peak . . . . . . . . 
viii

FIGURE

PAGE

12. Olympic marmot burrows into terrace risers adding to downslope movement 27

13. Olympic mountain goats frequent the terraces to graze . . . . . 28

14. Hiking trail cuts across terraces and

lobes frequently collapsi onto the trail . . . . . . .

15. Lobes measured at Maiden Peak : •..' 36

16. Lobes measured at Gray Wolf . : •. 37

17. Di'stribution of species and their

importance values within

communities across a turf-banked

terrace......... 46

18. Cross-section of excavated lobe \#3. • 51

19. Cross-section of excavated lobe \#10 • 54

20. Cross-section of excavated lobe \#15 - 56

21. Saturated soil below a late-lying

snowbank ........ 60

22. Pressure from flowing soils occasionally

results in collapsed lobe risers

23. Many of the trees have bent tree trunks

as a result of downslope movement. 66 
CHAPTER I

INTRODUCTION

Turf-banked terraces are landforms resulting from solifluction and frost creep. Solifluction is the actual moving of saturated soil, frost creep is a "ratchet-like" movement caused by freeze and thaw. Although both processes contribute to the formation of turf-banked terraces, solifluction is generally thought to be the major factor in their origin. Solifluction was first defined by Andersson in 1906; "This process, the slow flowing from higher to lower ground of masses saturated with water (from snowmelt or rain), I propose to name solifluction (derived from solum, 'soil' and fluere 'to flow')." (Andersson, 1906, p. $95-96$,

Solifluction is best developed beyond the treeline in alpine and arctic areas. Solifluction generally is believed to move slightly faster than creep and requires fine material saturated by snowmelt or rainfall. Under its own weight the soil moves downslope. This oan be imaginatively compared to icing flowing down the side of a cake. One of the chief forms resulting from this process are lobes of soil collectively termed turf-banked terraces. The lobes have gently sloping treads, steep risers, and a sharp 
angle immediately below the riser where snow accumulates (Figure.1).

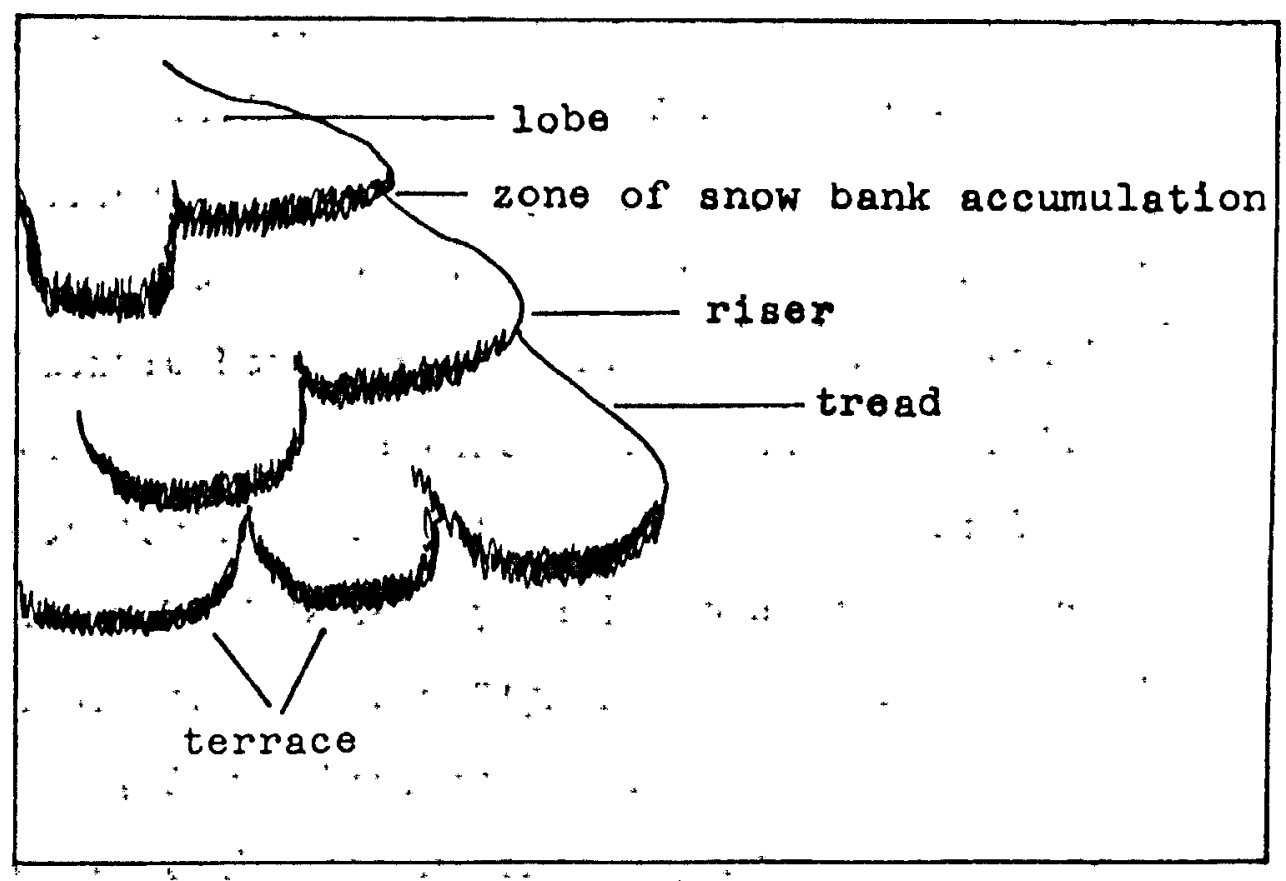

Figure 1." Turf-banked terraces and component parts

Turf-banked terraces and other similar forms have been referred to as solifluction lobes, benches, flows and sags, so11 flows, festoons, garland, steoped crescents, stonebanked terraces and turf-banked detritus benches.

Selected authors have found this phenomenon throughout the world: Antevs, 1932, on Mt. Washington in New Hampshire; Benedict, 1970, in the Rocky Mountains of Colorädo; Billings and Mark, 1961, in New Zealand; Jahn, 1960, in Spitsbergen; Price, 1970, in the Ruby Range of the Yukon Territory; Rudberg, 1958, in Sweden; Washburn, 1947, on Victoria Island; and Williams, 1957, in Norway. 
Turf-banked terraces frequently form a series of steps, one below the other, as in a giant staircase. Solifluction is a predominant process of denudation in alpine environments.

Turf-banked terraces are well-developed in the northeast section of the Olympic Mountains, Washington. They are not widely found in the other mountains of the Pacific Northwest, however. I became intrigued by this fact and by the factors controlling the distribution and development of solifluction. The question of larger distribution is beyond the present purpose. My study is based only on the 0lympic Mountains. The major thrust of my investigation is aimed at answering the question: What is the nature of turf-banked terrace development in the 0lympic Mountains? Why do they occur, and what is their local ecological significance?

The major field investigations were carried out during the summer, 1975, with the help of my willing and enthusiastic field assistant, Barbara Kennedy. I first become interested in solifluction while participating in the 1974 Geography Summer Field Camp, Portland State University under the direction of Dr. Larry Price. Dr. Larry Price aloo visited the study area twice during the summer of 1975. Research funds were provided through a research grant from the Mazamas, a mountaineering club of Portland, Oregon. 


\section{CHAPTER II}

\section{AREAL SETTING}

The Olympic Mountains are located on the Olympic Peninsula in the northwestern corner of Washington state. The Peninsula is bounded on the east by Puget Sound, on the north by the Strait of Juan de Fuca, on the west by the Pacific Ocean, and on the south by the Chehalis River Valley, Olympic National Park, with an area of $3367 \mathrm{~km}^{2}$, was established in 1938 and encompasses most of the mountains of the Olympic Peninsula.

An overview of the olympic Mountains reveals a pattern of steep-sided ridges radiating from Mount 0lympus. Sumit elevation increases from the northwest toward the southeast and the eastern olympics are more rugged than the western part of the range. Drainage follows the somewhat radial pattern of ridges. Major rivers include the Hoh, Bogachiel, Soleduck, Elwha, Dungeness, Dosewrllips, Duckabush, Skokomish, Wynoochee, Humptulips, Quinault, and Queets (Figure 2).

\section{GEOLOGY}

Two major rock formations form most of the Olympic Mountains. The Soleduck Formation is the most extensive, 


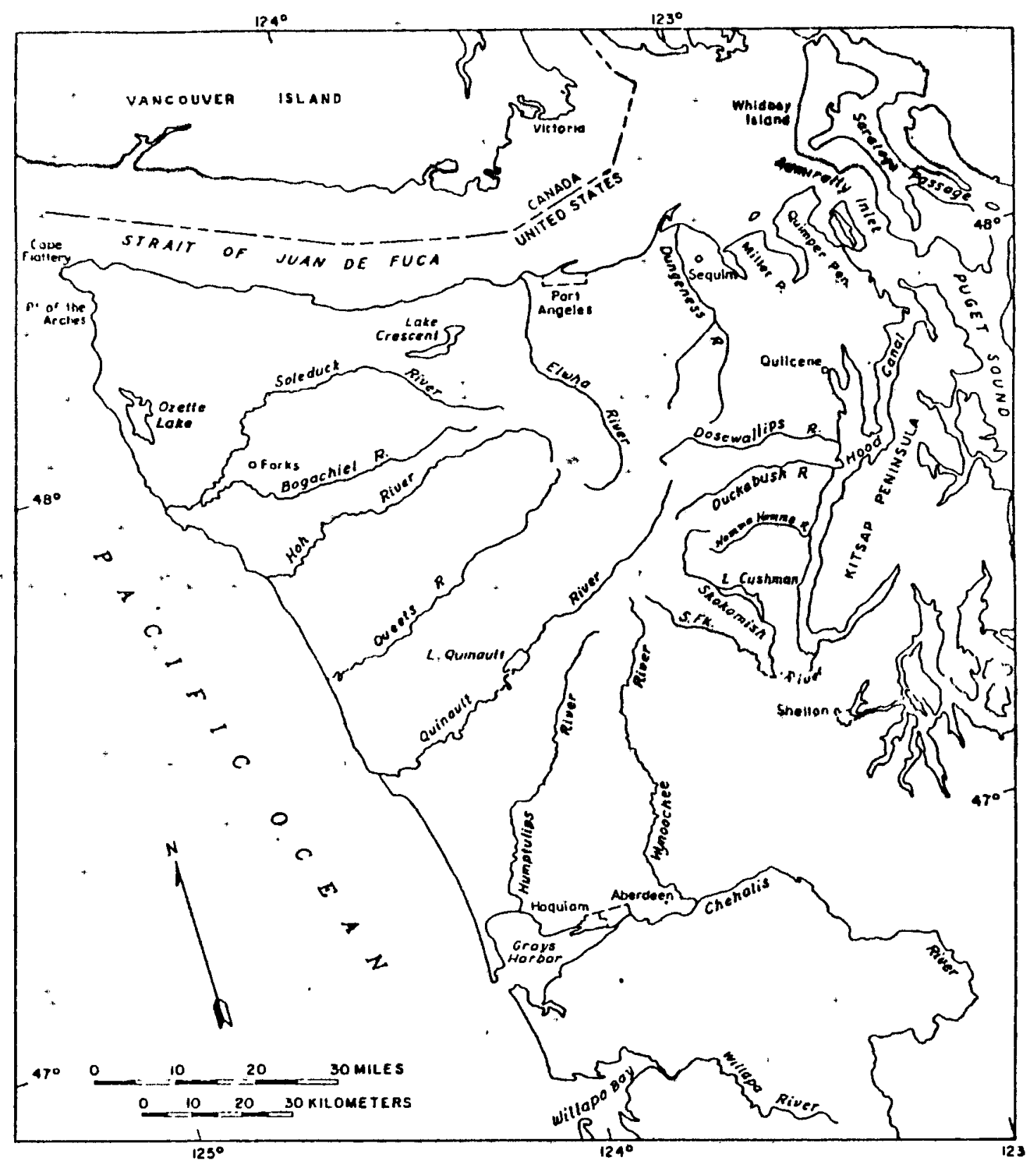

Figure 2. Stream patterns in the 0lympic Peninsula (Tabor, i975, p. xv). 
making up the entire core of the range (Figure 3). It consists of dark sandstone, siltstone, altered submarine balsaltic rocks, and bedded chert of Eocene and Oligocene age. These rocks were deposited over oceanic basaltic crust, and oceanic fosisils can be found within the various strata. The second rock unit, known as the Crescent Formation; is predominantly basaltic lava of Eocene age. It consists of eruptives whose submarine origin is indicated by marine fossils contained in interbedded sedimentary rocks and by the development of pillow structure in the flows (McKe日, 1972, p. 161). From near Flattery at the northwest corner of the peninsula, the Crescent Formation crops out in a band around the north and east side of the olympics (Figure 3).

Although the Crescent basalt appears to overlie the Soleduck sedimentary rocks it is the older of the two units. An explanation of this reversal of superposition by Tabor (1975), based on plate tectonics is shown on Figure 4. The Crescent Formation seems to have been rafted against the continental margin. Although slightly folded, the great mass and the rigidity of the basalt protected it from extreme deformation (Tabor, 1975), (Figure 4). The Calawah fault zone separating the relatively simple structures of the crescent in the northern periphery of the range from the more complex structures in the core 


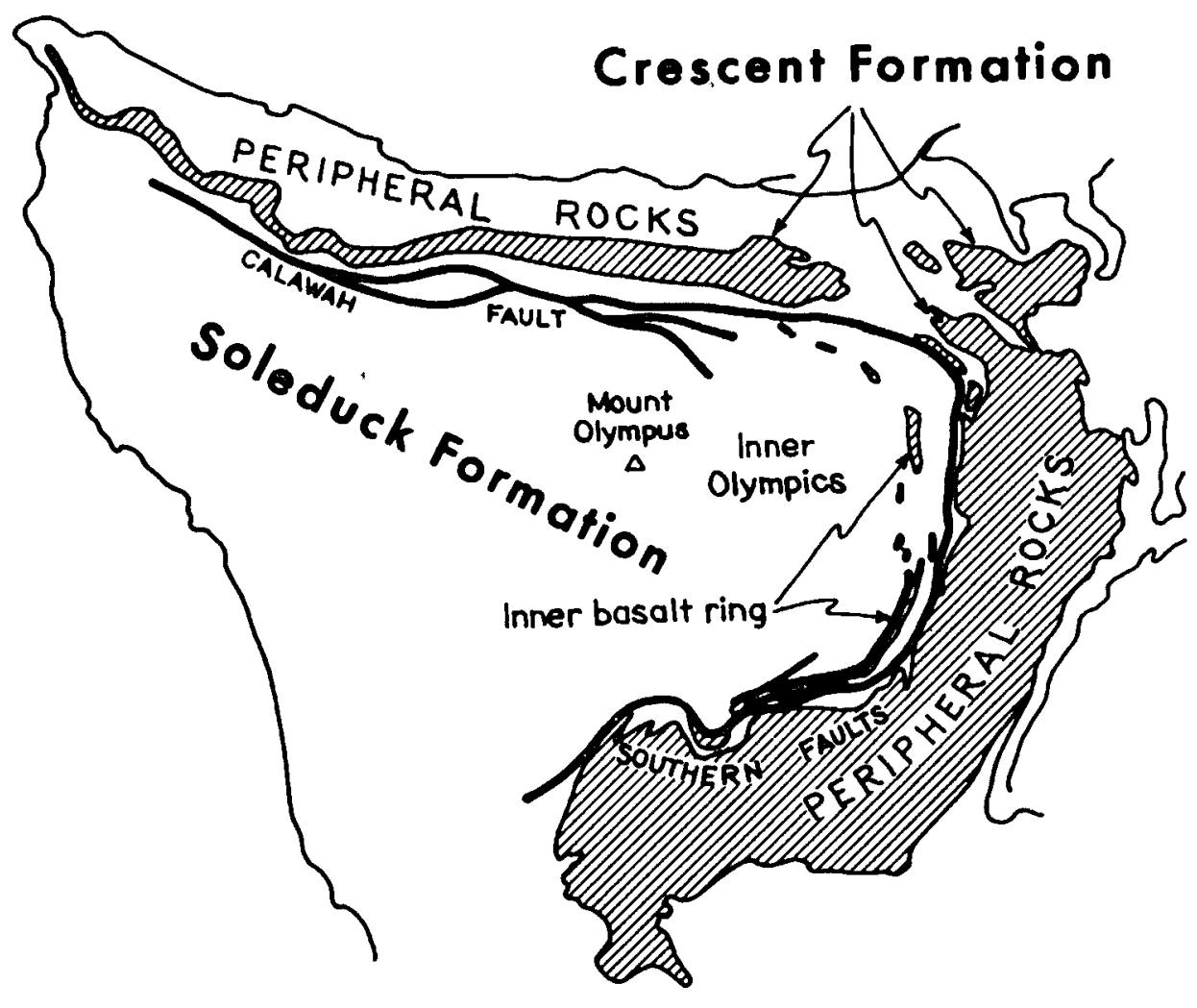

Figure 3. Predominant geologic features of the Olympic Mountains (Adapted from Tabor, 1975, p. 24). 

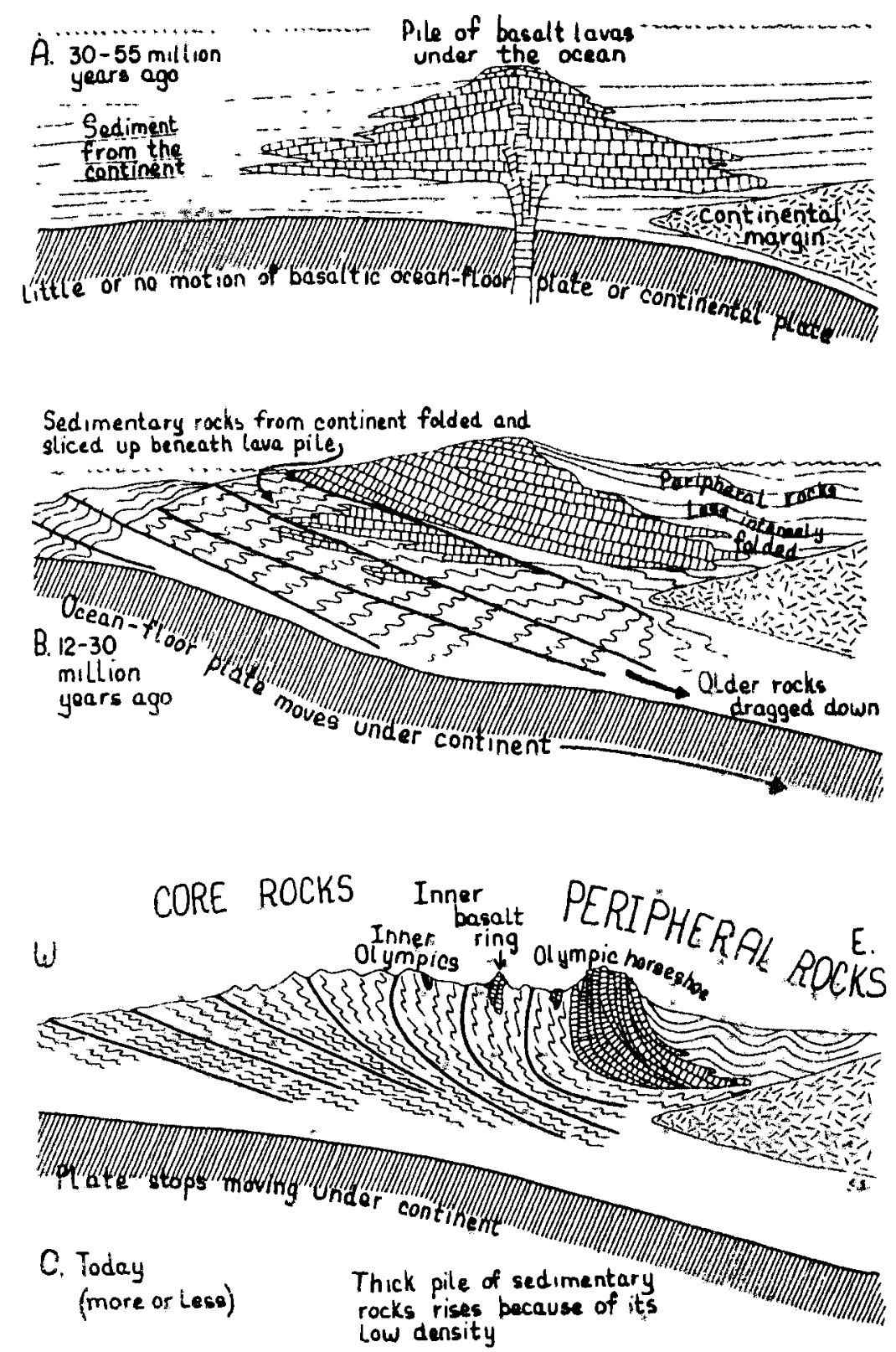

Figure 4 , Development of the Ozmp:c Mountains TTabor, 1975, p. 35). 
(Figure 3) suggests that the younger Soleduck rocks were brought into their present position by fault movement (Tabor, 1975, p. 28). The thinner, less rigid, sedimentary rocks were not only folded and sliced as they collided with the continent, but they were also pushed down to new regions of hagher temperatures where new minerals such as muscovite and chlorite began to form (Tabor, 1975, pp. 34, 109).

\section{GLACIATION}

The Olympics have been greatly dissected by alpine glaciers. U-shaped valleys transect the sedimentary ridges (Figure 5).

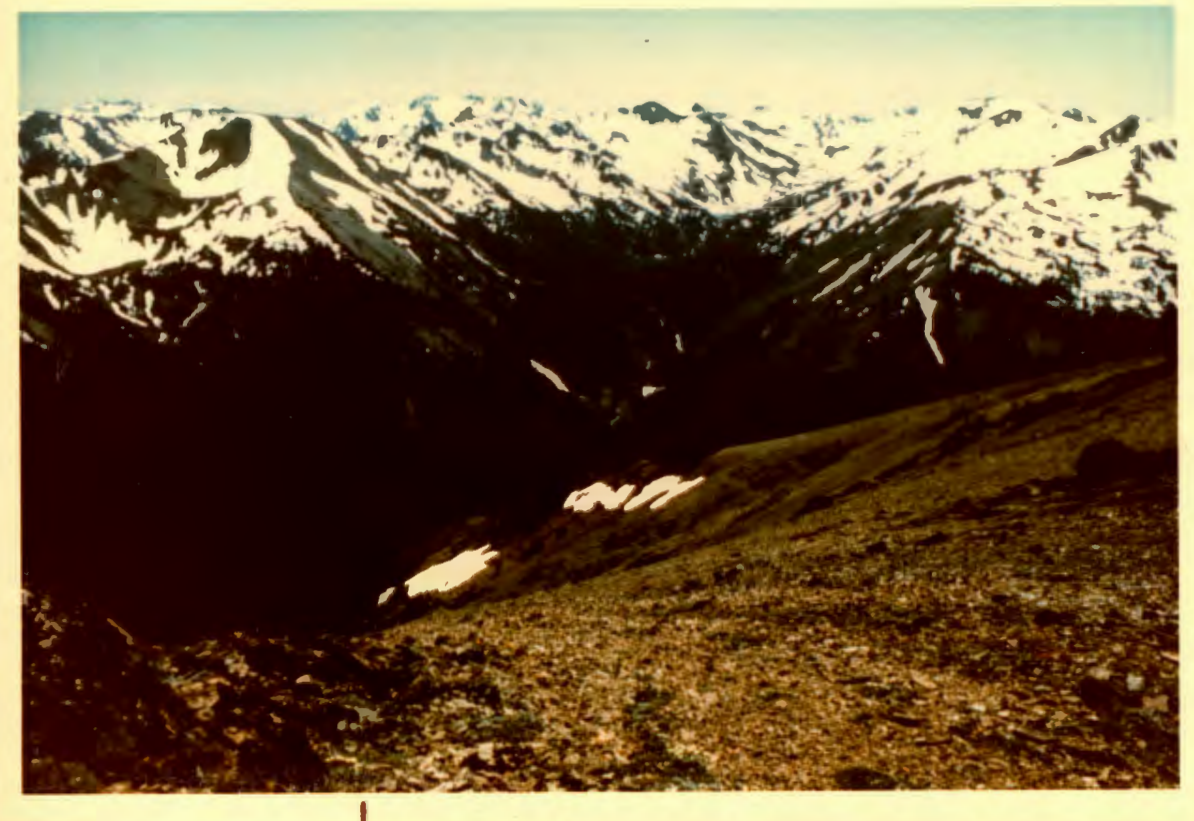

Figure 5. U-shaped valleys transect the sedimentary ridges. 
Numerous cirques, tarns, and moraines are evident throughout the range. In this strongly maritime environment, glaciers are present at lower elevations than elsewhere in the Northern Hemisphere at similar latitude (Hubley, 1956, p. 671). More than 50 active alpine glaciers cover an area of $60 \mathrm{~km}^{2}-80 \mathrm{~km}^{2}(25-30 \mathrm{sq}$. mi.). The largest concentration of glaciers is on Mount 0lympus, where six 1ce fields cover an area of $40 \mathrm{~km}^{2}(15 \mathrm{sq} . \mathrm{mi}$.$) . Three major$ glacial advances occurred in the 0lympic Mountains during late Pleistocene time (Crandell, 1965, p. 347). Olympic alpine glaciers had extended into the lowland valleys during the Evans Creek Stage and then retreated substantially before the arrival of Vashon continental ice, 17,500 years ago (Long, $1975, \mathrm{p} .86$ ). The advancing continental ice sheet either overtook the retreating local glaciers or joined the descending alpine glaciers. Many Olympic mountain glaciers attained a large size after the maximum of the most recent continental ice, and at some places mountain glacial drift overlies Vashon continental drift (Long, 1975, p. 86). Granite erratics deposited by the continental ice sheet mark the extent of continental ice glaciation in the 0lympics. On the northwest ridge of Blue Mountain (northeastern 0lympics) the upper erratic limit lies at $1173 \mathrm{~m}(3850 \mathrm{l})$, (Long, 1975, p. vii). 
The precipitation shadow of the Olympic Mountains is reflected in the eastward or northeastward increase in mean altitude of glaciers. Figure 6 shows a theoretical surface

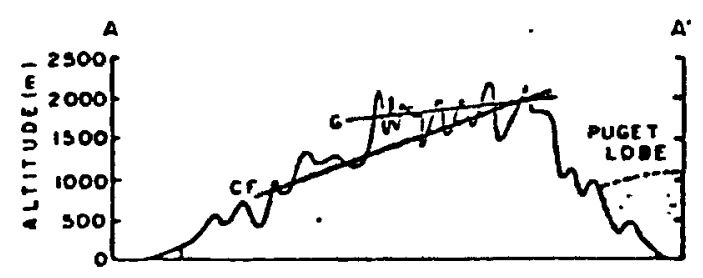

Figure 6. A theoretical surface connecting small modern glaciers and a surface connecting Pleistocene cirque floors. (Porter, 1964, p. 480.)

connecting small modern glaciers $(G)$ and a surface connecting Pleistocene cirque floors (CF). The line of modern glaciers rises inland less steeply than the one of Pleistocene glaciers, and the two intersect in the northeast part of the range (Porter, 1964, p. 480).

- The northeast alpine ridges have not been glaciated but were nunataks above the alpine glaclers. Having been exposed to weathering agents 'over a great span of time, soil has developed and accumulated on the ridgetops making them rounded and gentle. This has important implications to the distribution of solifluction.

Present glacial activity gives indication that there is also periglacial activity in the olympics today. In 1955. Hubley found that three Olympic glaciers were advancing at very slow rates and one showed considerable increase 
in ice thickness up-glacier from its terminus. Many of the small cirque glaciers remained completely snow covered throughout the ablation seasons of 1952-1955, and since 1954 the terminus of the Blue Glacier has advanced (Hubley, 1956, p. 671-674). The glaciers of Mt. Olympus are currently being monitored by University of Washington geologists and geographers.

\section{CLIMATE}

The outstanding climatic characteristic of the olympic Mountains is the striking contrast between heavy precipitation on the west. side and the relatively low precipitation in the northeast sector. Winter storms from the southwest drop a mean annual precipitation of more than $3000 \mathrm{~mm}$. $\left(120^{\prime \prime}\right)^{\prime}$ at Mount Olympus (Figure 7). However, as the storms pass on toward the northeast direction, a rain shadow develops so that, Hurricane Ridge receives about. $1000 \mathrm{~mm}\left(40^{\prime \prime}\right)$ precipitation while only $500 \mathrm{~mm}\left(20^{\prime \prime}\right)$ fall at the town of Sequim (Figure 7). Summer winds from the northwest produce cool, relatively dry conditions. Fog drip, however, contributes to damp conditions throughout the olympic Mountains during much of the year. On the Olympic Peninsula within a distance of $65 \mathrm{~km}$ ( $40 \mathrm{miles}$ ) are recorded the heaviest precipitation in the continental United States as well as one of the drier spots on the 


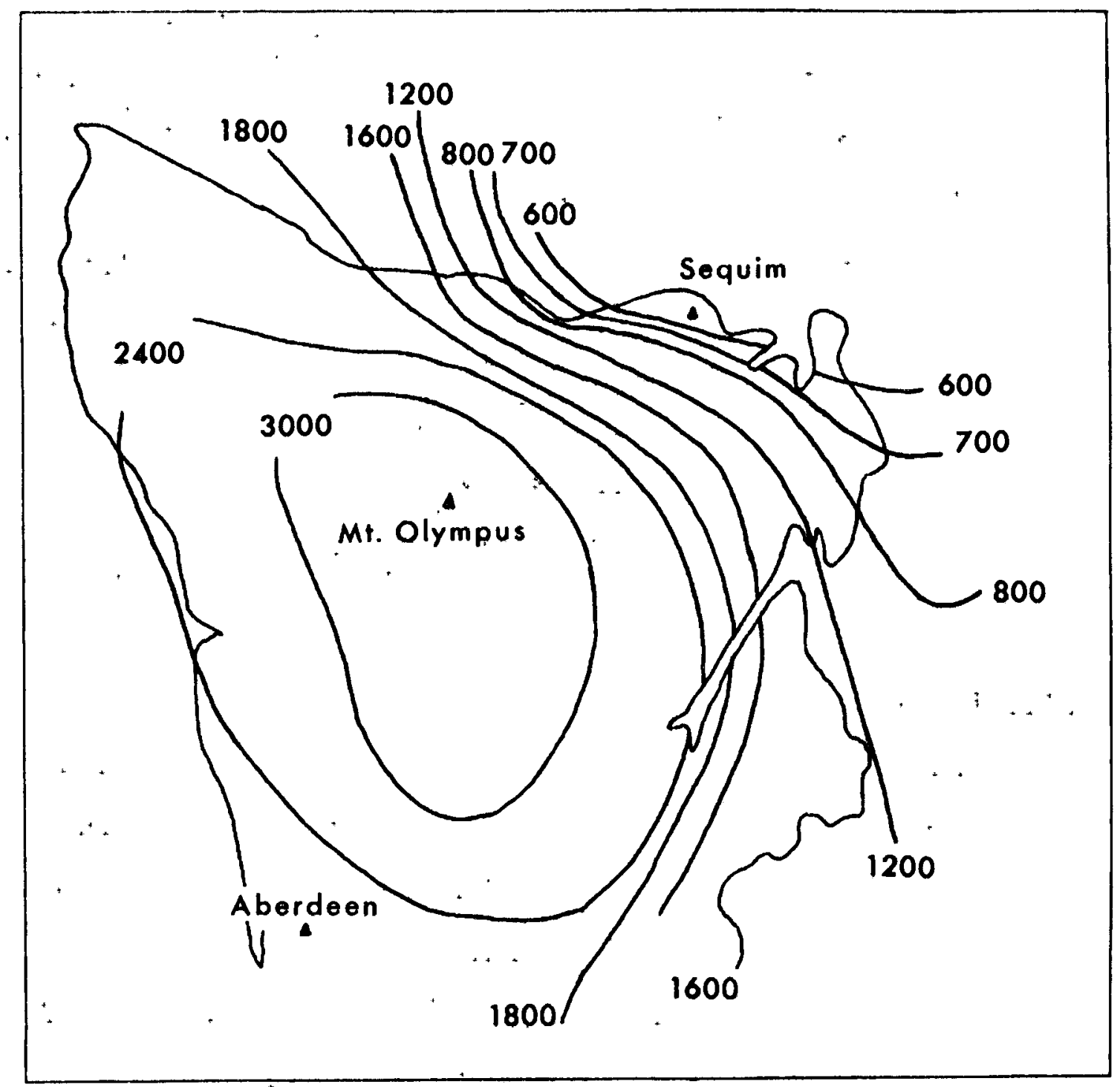

Figure 7. Precipitation in millimeters for the Olympic Mountains (Adapted from Climates of the States, 1974, p. 955). 
Pacific Coast (Jones, 1936, p. 12).

Very little is known of the alpine climate here, although Blise (1966) provides some very general microenvironmental data for two alpine stations (Table I.). As can be seen, surface temperatures are higher than either $10 \mathrm{~cm}$ (4") above or $10 \mathrm{~cm}$ (4") below the surface. Temperatures within cushion plants at $1972 \mathrm{~m}$ (6468') Precipitation, winds, and temperatures tend to increase from June to August, and there is a diminishing, amount of solar radiation.

\section{SOIIS}

There are four major types of solls in the 0lympics. The most widespread soil type is that derived from the Olympic's sedimentary core. It consists of sandy and silty loams and comprises $80 \%$ of the mountain soils. When occurring on moderate to steep slopes the soils (termed Spodosols or Podsols) have thin A or B horizons due to erosion, whlle on flat to moderate slopes soils (termed Entisols or Lithosols) have little horizon development as the result of recent deposition.

Alpine soils, derived from sedimentary rocks, often have a soft surface horizons (mollic layer) caused by decomposition of dead grass, or, as a result of abunant surface water, have a dark organic surface layer and an 


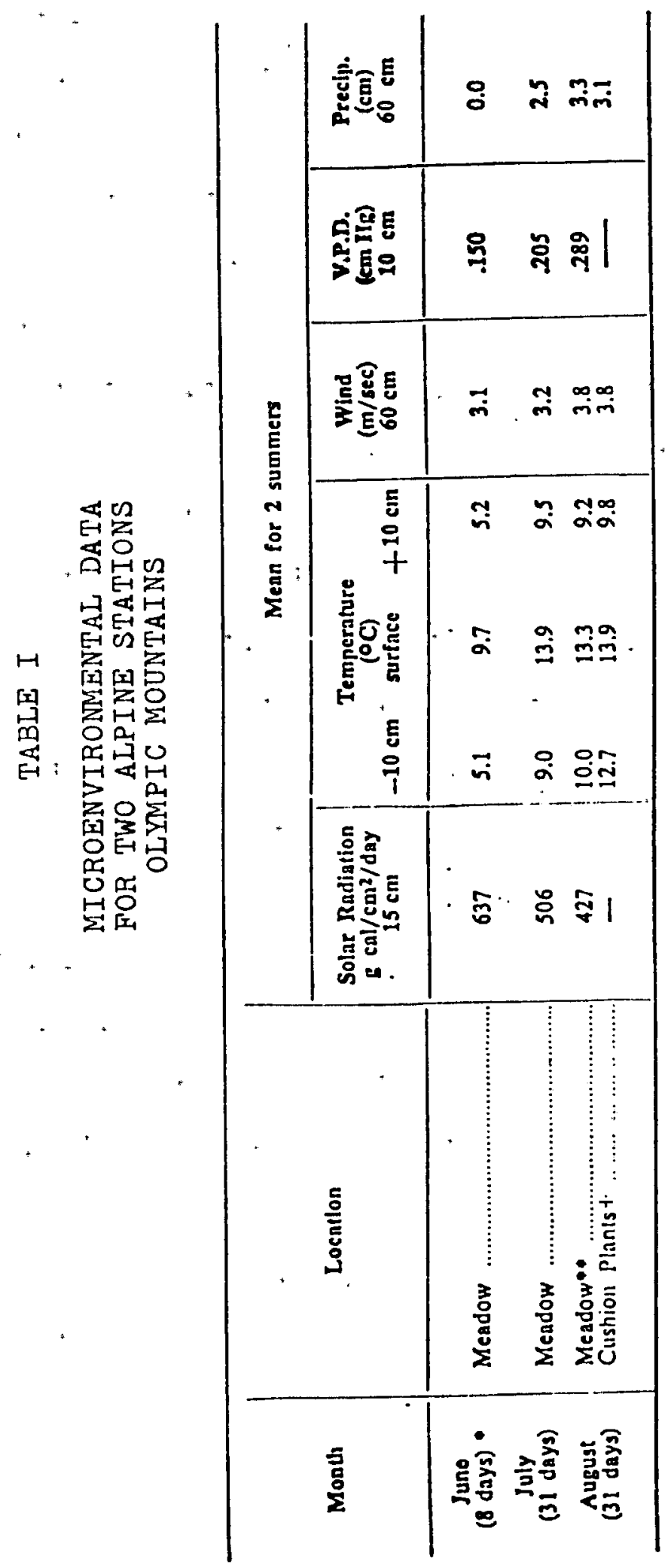

ô
-1
$\dot{0}$
0
0
0
-1
0
0
0
-1
0 
overall grey-brown loam surface.

The second major soil is one derived from parent material consisting of pillow basalt and breccia. ContainIng a major quantity of 1ron, this soil is termed a roddiahbrown laterite or 0xisol. If sufficient moisture is avallable

a thin humic surface layer will develop. These soils have a medium to high susceptibility to dissection and erosion.

A third division is the alluvial soils. These soils are found on alluvial flats and narrow valley slopes along rivers and creeks. Because of recent deposition, these Entisols (Low Humic Gley soils) have little profile development. The soils are moist, especially on the terraces, as a result of the tremendous snowmelt from higher elevations and river flow throughout the summer. The texture ranges from a deep silty loam to a very fine, sandy loam.

The fourth major division are those solls derived from glacial deposits. Various soils developed in glacial till at high elevations are termed Inceptisols (Tundra soils). Found in the high, northeast section of the olympic Mountains; these are young soils with little profile. The soils on the steep mountain slopes lack stability and their accumulation is retarded by the action of wind, water, and solifluction. 


\section{VEGETATION}

The vegetation of the olympics is one of the outstanding resources of the peninsula. Vegetation patterns are primarily controlied by topography and precipitation. Exposure, temperature, wind, and soil material are factors of seoondary influence.

A rich rain forest of Picea sitchensis (Sitka spruce), Tsuga heterophylla (Western hemlock), and Thuja plicata (Western redcedar) occurs along the coastal zone. Eastward, between $550 \mathrm{~m}$ and $1100 \mathrm{~m}\left(1800^{\prime}\right.$ and $\left.3600^{\prime}\right)$ forests of Abies amabilis (Pacific silver fir) and Tsuga heterophylla (Western hemlock) occur on alluvial flats and narrow valley slopes. where soil is moist and air is cool. This forest type comprises the most extensive community in the western 0lympics. In the drier, eastern section of the Olympic Mountains, between $600 \mathrm{~m}$ and $1100 \mathrm{~m}$ (1970' and 3600') Tsuga heterophylla and Psoudotsuga menziesil (Douglas fir) forests make up the dominant type. Higher summer temperatures, low sumer precipitation, occasional fires, and welldrained soils favor the Douglas Fir in this region as opposed to the western flaniss of the mountains.

Subalpine forests of Abies amabilis (Pacific silver fir) and Tsuga mertensiana (Mountain hemlock) occur botween $.1100 \mathrm{~m}$ to $1650 \mathrm{~m}\left(3608^{\prime}\right.$ to $\left.5412^{\prime}\right)$ and on north-facing slopes of the central mountains between $1125 \mathrm{~m}$ to $1400 \mathrm{~m}$ 
(3690' to 4592'), where precipitation is high and temperatures cool (Fonda and Bliss, 1969, p. 280). Subalpine forests of Abies lasciocarpa (Subalpine fir) occur in the eastern 0lympics on higher, exposed ridges along with Pinus contorta (Lodgepole pine) in fire-disturbed areas. Subalpine and alpine vegetation are found within the 0lympic Mountains only eastward of Mount 0lympus. West of this highest mountain barrier the ridges are not high enough to support subalpine or alpine growth. Timberline in the northeastern Olympic Mountains occurs at $1725 \mathrm{~m}$ (5750'). This relatively low limit of treeline apparently results from the heavy snowfall and excessive cloudiness. The Olympics are the only mountain region in the Coast Range high enough to reach the climatic timberline. Subalpine meadows exist in the dry, northeastern mountains to elevations of $2000 \mathrm{~m}$ (6560') and in the north-central mountains to $1350 \mathrm{~m}$ (4430') (Kuramoto and Bliss, 1970, p. 319). Above the limits of tree growth exists an arcticalpine zone where soil is shallow, growing season short, winds desiccating, and temperatures extreme。 Vegetation consists of dwarfed, shrubby cushion plants. sedges and rushes, mosses and lichens. The three largest plant families represented in this zone are the Compositae, Gramineae, and Gyperacere (Jones, 1937, p.21)。 Patterns of alpine communities in the olympic Mountains are influenced 
more by the time of snowmelt and accumulation of snow in relation to aspect than by any other set of factors (Bliss, 1969, p. 175). 
CHAPTER III

\section{DESCRIPTION OF STUDY SITES}

A two hour reconnaissance by air was made over the Olympic Mountains to plot the distribution of turf-banked terraces as well as to seleot the detailed study sites. The most striking discovery of the flight was that the terraces are limited only to a small area on the northeast side of the olympics (Figure 8). Two study sites were selected within this area on the basis of the quality of lobe development as well as of accessibility. The environmental conditions in both study sites are similar. The first site, Maiden Peak, is Located approximately $5 \mathrm{~km}$ ( 3 miles) east of the Deer Park Campground along the Obstruction Peak trail ('A' on Figure 8). After passing through Grassy Valley, the trail climbs up and along the eastern peak of the Maiden Peak ridge. This saddle, referred to as the Maiden Peak saddle, has turf-banked terraces on the north-, northeast-, and northwest-facing slopes (Figure 9). The west-facing slope leads to a glacial cirque at the bottom of which lies Maiden Lake. The elevation of the Maiden Peak saddle ranges from $1725 \mathrm{~m}$ to $1860 \mathrm{~m}$ $\left(5750^{\prime}\right.$ to $\left.6200^{\prime}\right)$. 


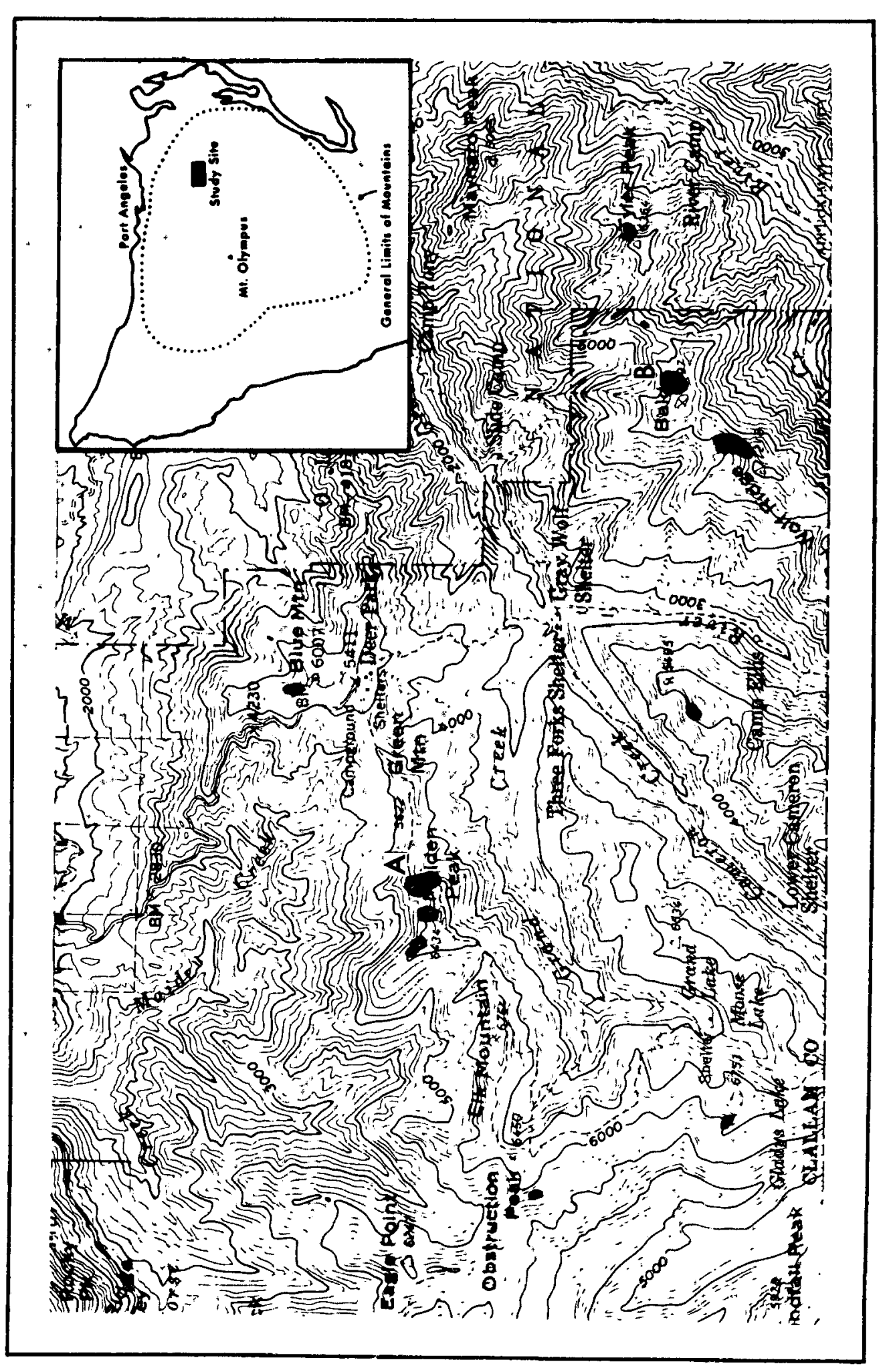

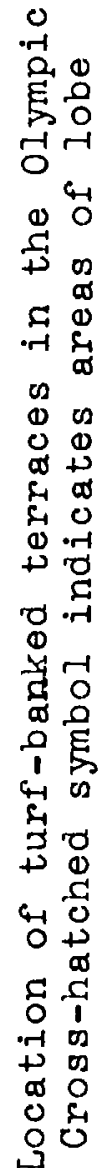

我落 


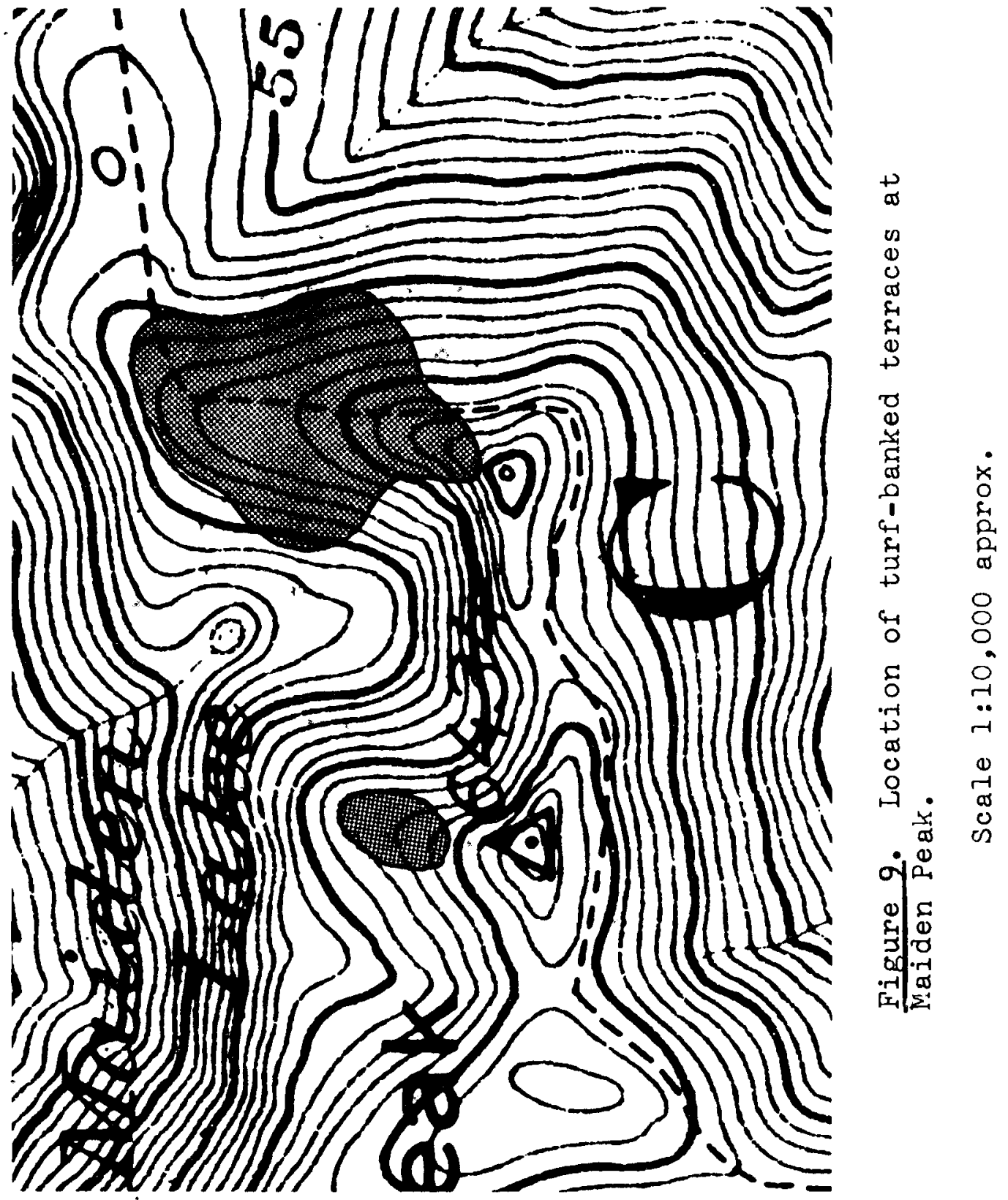


The second study site was established at the Gray Wolf cirque ('B' on Figure 8). The cirque lies on the northeast side of Gray Wolf ridge, north of Royal Basin and southwest of Baldy Mountain. The area is reached by a strenuous hike up Maynard Burn Way, an unkept fire trail which begins near the confluence of Royal Creek and the Dungeness River. The trail ends close to Baldy Mountain, whereupon one must walk cross-country in a southwesterly direction along the Gray Wolf Riage until the cirque is reached. The cirque, with an inactive rock glacier in the center, cannot be confused with other smaller cirques nearby. At the toe of the rock glacier lies a small, snow-fed 1ake. Terraces are found on the northeast-, north-, and northwest-facing slopes within the cirque (Figure 10). The elevation of the terraces ranges from $1725 \mathrm{~m}$ to $1950 \mathrm{~m}$ (5750 to $\left.6500^{\prime}\right)$.

Because of a maritime influence, cold conditions persist longer into the spring and summer at lower altitudes In the Olympics than in more continental areas. This favors a prolongation of both glacial and periglacial conditions in the alpine areas of the Olympic Mountains. Prevailing southwesterly winter winds free south-facing slopes of snow early in winter and redeposit the snow on northeast-facing slopes. This deposition provides melt water to the soil late Into spring. The top of the Maiden Peak saddle is subjected to harsh wind abrasion and dessication and becomes 
24

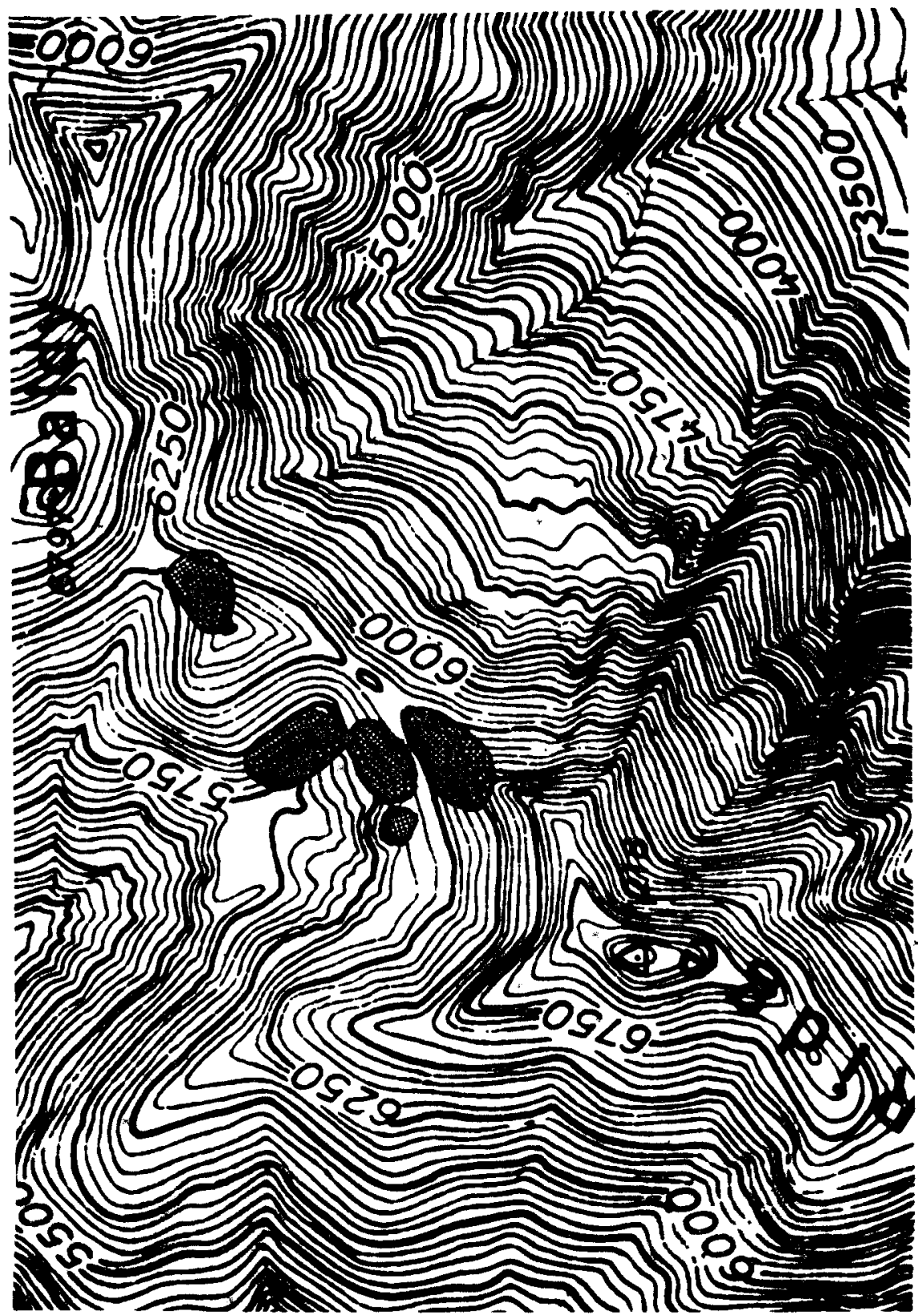

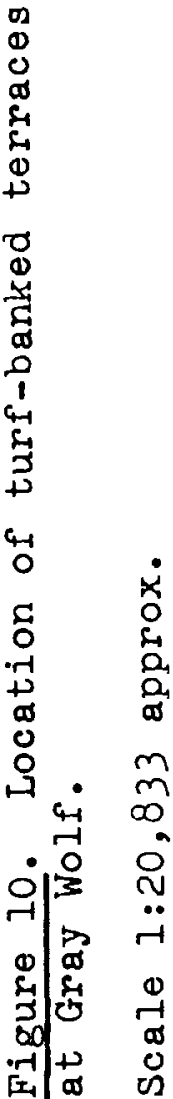


free of snow in the spring while side slopes are still snow covered. Because of lack of snow, water, and vegetation, no terraces have developed on the saddle top. The influence of winds on terrace development is especially evident on a slope inside the Gray Wolf cirque. Southwesterly winter winds channel around the south side of the cirque head and blow into the cirque. Turf-banked terraces, developed on the east-facing slope of the cirque, are oriented in a northeast direction rather than immediately downslope, because of wind influence in snowbank accumulation and melting. This can be seen, not only by the shapes of the terraces, but also by the moister vegetation comminties on the northeast-facing side of the lobe fronts (Figure 11).

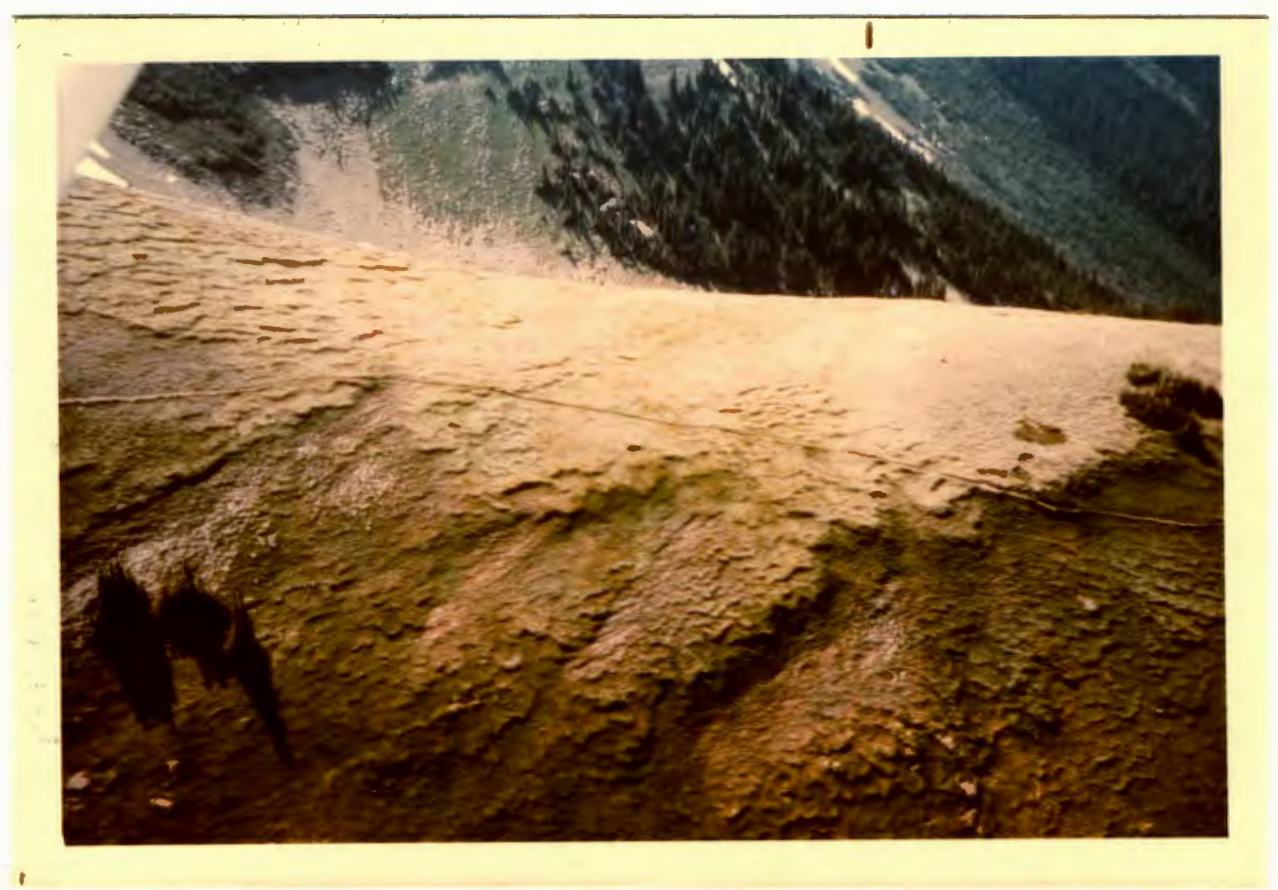

Figure 11. Terraces flow at an angle to the slope on the northeast-facing slope at Maiden Peak. 
The rock type of both sites is of sedimentary origin and weathers into fine-textured sandy soils with some silt and clay. Many rock fragments are found on the soil surface and, where the soll is bare of vegetation, the rock fragments are often sorted into patterned ground features. The soil color is a dark-yellowish brown $(10 Y R / 3 / 4)$ to a dark-grayish brown $(10 Y$ R/4/2) and depth varies from $5 \mathrm{~cm}$ to over $1 \mathrm{~m}$ ( $2^{\prime \prime}$ to over $\left.4^{\prime}\right)$.

Both study sites have a fairly complete ground cover of alpine vegetation consisting of low, matted, woody plants, grasses, sedges, and lichens. Communities of cushion plants, e.g., Phlox diffusa and Douglasia laevigata dominate in areas where bedrock is exposed at the surface and the substrate appears stable. Active, patterned ground features are frequently vegetated with Lupinus lepidus, Phlox diffusa, Synthyris languinosa, and Douglasia laovigata. There is a transition from subalpine to alpine species across the Maiden Peak saddle. Alpine species, e.g., Lupinus lepidus exist on the dessicated, harsh, exposed saddle seat, while the subalpine species, e.8., Lupinus latifolius grow on the more favorable, less exposed slopes of the saddle.

There are usually no trees growing on the terraces, due to the instability and harshness of the area. A small clump of subalpine firs does exist, however, on the northeast 
side of the Maiden Poak saddle and on the eastern edge of the Gray Wolf slope. Where conditions are slightly more stable and less harsh, these trees had apparently become established during a period of inactivity within the terraces.

Various burrowing mammals live on Maiden Peak including the 0lympic Mărmot (Marmota olympus), Townsend Chipmunk (Eutamias townsdendii), and a vole (Microtis organinsus). Their burrows are frequently located on the terrace risers. The soil they excavate is pushed into a mound below their burrow entrance, adding to the downslope movement of soil (Figure 12). Price (1971b, pp. 100-106)

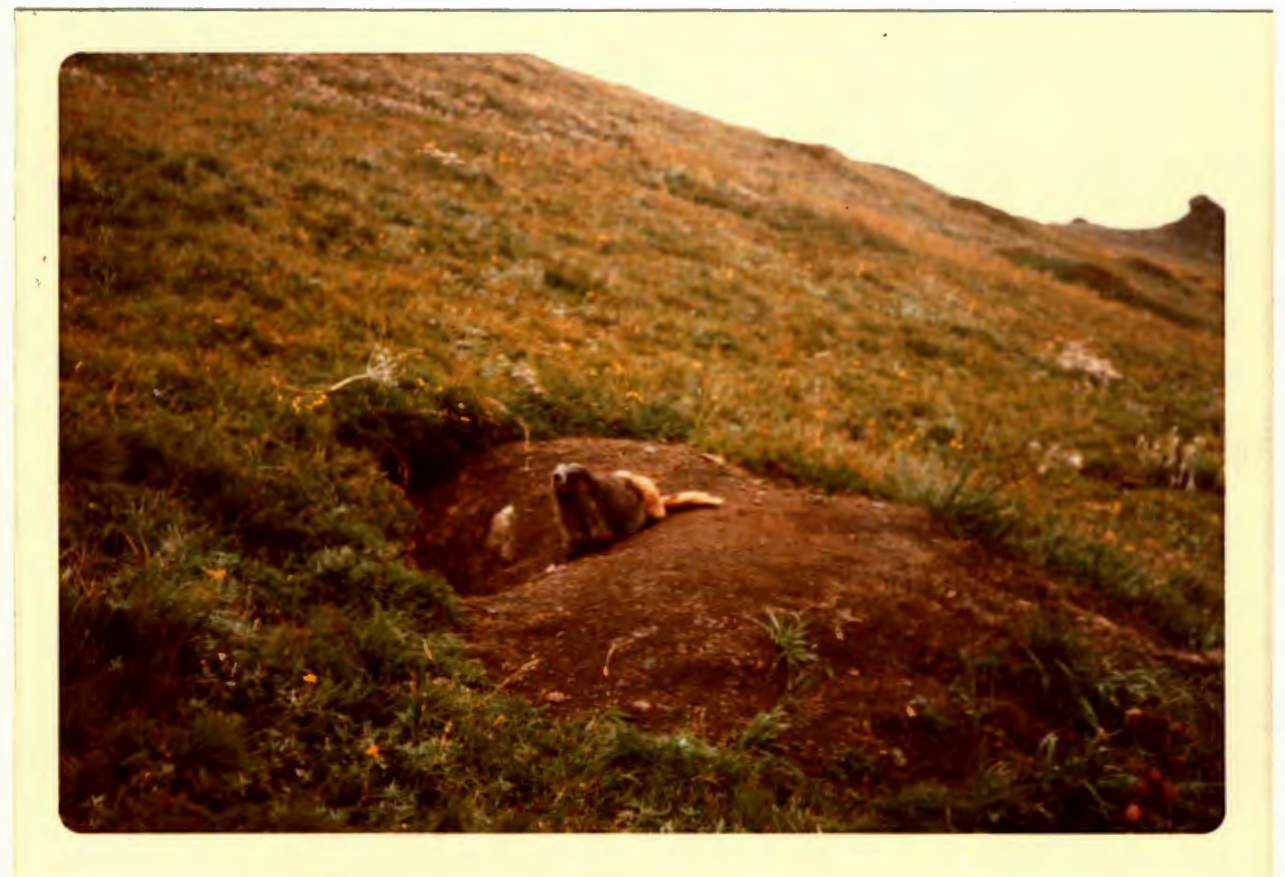

Figure 12. Olympic Marmot burrows into terrace risers ading to downslope movement. 
found that ground aquirrels burrow mainly in the lee of small lobes, and constantly replenish the surface with fine material. Johnson and Billings (1962, p. 114) found that pocket gophers aid in creating steep environmental gradients in short distances. The horned-lark (Eremophila alpestris) has been found nesting on the terraces as well as frequently flying close to the ground over the terraces although no geomorphic effect seems to be attributable to this bird. As many as seven Columbia Black-tailed deer have been seen grazing on the terraces. Their removal of vegetation as well as their weight on the slope in spring when the soil is wet and soft contribute to soil movement. Olympic Mountain goats (Oreamnos americanus) frequent this saddle to graze (Figure 13). They have been observed

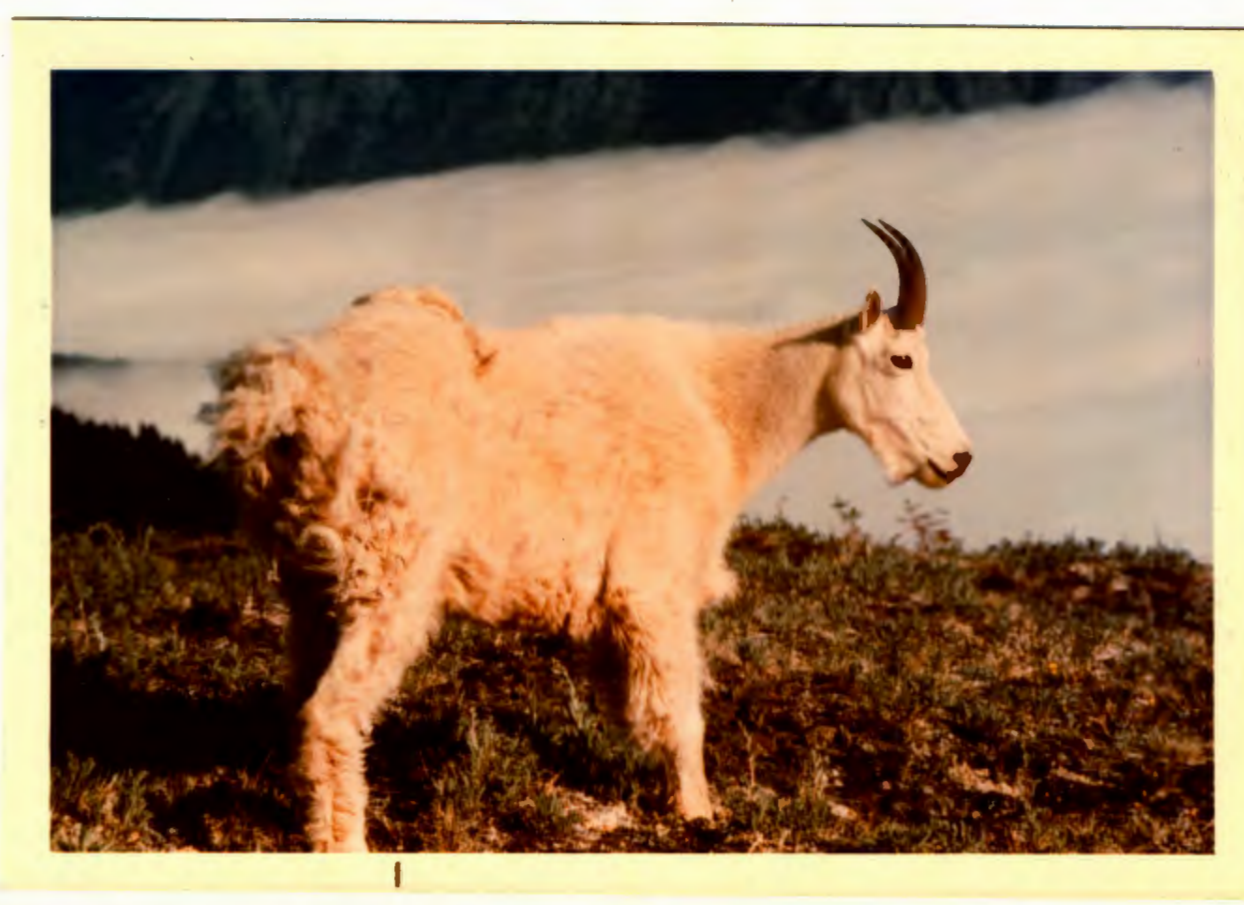

$\frac{\text { Figure 13. Olympic Mountain goats frequent the }}{\text { terraces to graze. }}$ 
digging holes, perhaps in search for grubs or roots, and the resultant hole averages $.60 \mathrm{~cm}$ by $.60 \mathrm{~cm}$ (2' by 21). Destruction of the turf enables frost to penetrate more deoply and faolitates washing of fines by aurface run-off.

A hiking trail, averaging $1 \mathrm{~m}\left(3^{\prime}\right)$ in width, cuts across terraces on the east-facing slope of Maiden Peak. Terrace risers overhang onto the trail up to $25 \mathrm{~cm}$ (10") and occasionally collapse onto the trail (Figure 14).

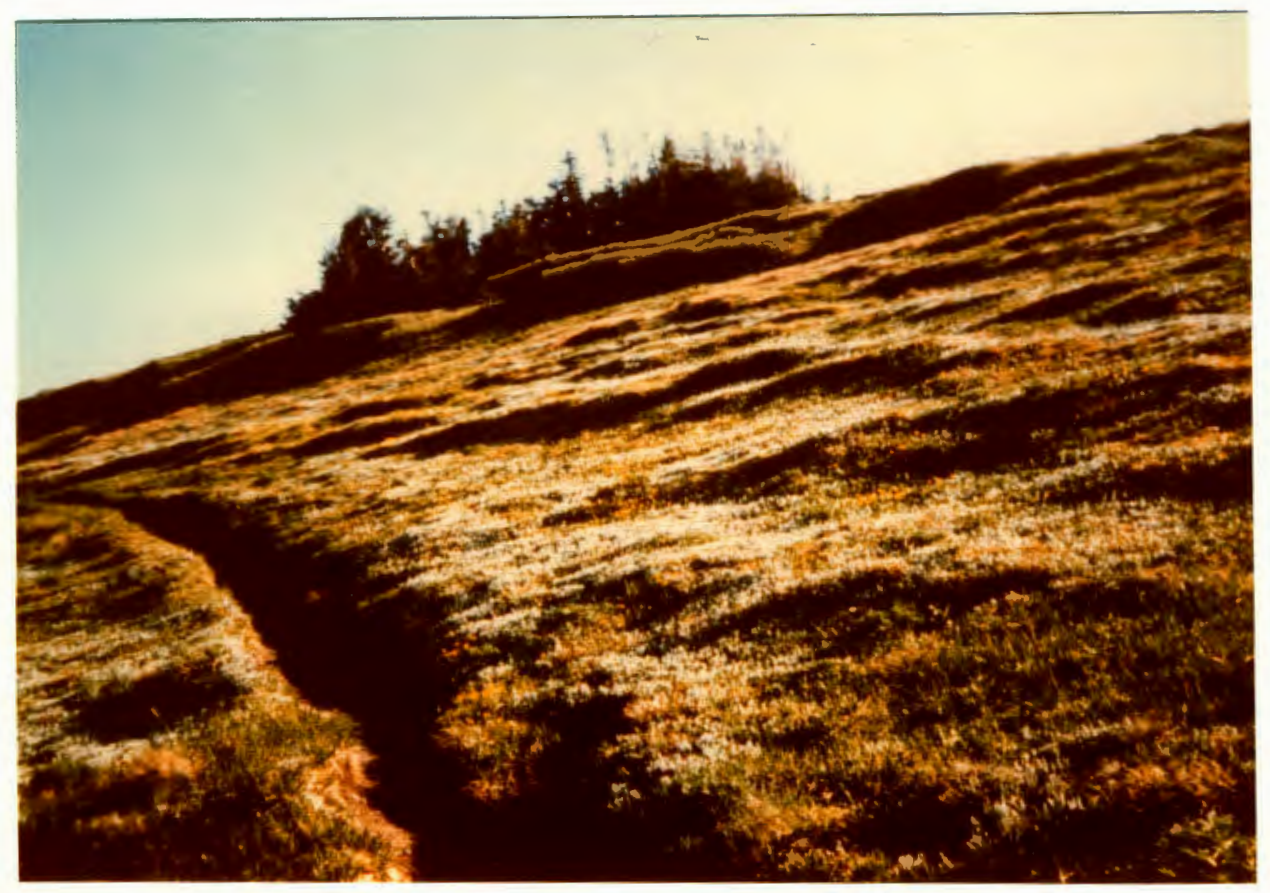

Figure 14. Hiking trail cuts across terraces and lobes frequently collapse onto the trail.

The soil on the trail is compacted from heavy hiking traffic and the ground becomes impermeable to water. 
Water is channolod along the trail and during hoavy snowmelt the channel becomes a tiny stream. At two points on the trail this water has caused mudflows and terrace lobes to form off the side of the trail: The trail does, however, prevent hikers from scattering across the entire slope and causing widespread destruction.

Terraces on the Maiden Peak saddle, particularly on its northern part, are frequently traveled over during summer by hikers looking for Maiden Lake. This slope affords the most easily accessible view of the cirque-lake. The damage to plant life is visible in crushed stems, flowers, and uprootings of plants. Very few hikers frequent the Gray Wolf study site because of its difficult accessibility. Bell and Bliss (1973, p. 26) studying alpine disturbances in the 0lympic Mountains, found that in both the snow accumulation and the stone-vegetation stripe communities, the effects of trampling were readily visible where travel frequency is medium to heavy. Loss of cover of both flowering and non-flowering plants occurred with five walks per day in both communities. The greatest portion of the damage apparently occurred with the first walkings, as most fragile plants disappear quickly (Belf and Bliss, 1973, p. 32). The study sites may have a history of fire (Kuramoto and Bliss, 1970) however, remnants of wood are found only on south-facing slopes。 


\section{CHAPTER IV}

\section{METHODS OF FIELD INVESTIGATION}

After locating two study sites based on the areal reconnaissance, we hiked to the areas. Actual field equipment included two Brunton compasses, an Abney hand level, a Munsell soil chart, a 30 meter steel tape, string, wooden stakes, a plant press, and a shovel.

At each study site slope orientation, slope angle, height of risers, and length of trieads were measured. Vegetation sampling transects were run across the terraces in order to ascertain ecological significance. Transects of $15.25 \mathrm{~m}$ (50') long were run on three slopes at Maiden Peak and on one siope at Gray Wolf.

Internal characteristics of the turf-banked lobes were ascertained by making excavations through three representative lobes. One lobe faced north at Maiden Peak, and one faced north on a ridge near Gray Wolf cirque. The excavation produced a trench running upslope in the middle of a lobe. Depth varied as to material found within; width was sufficient to'view soil profiles, and length of the trench varied from $2.5 \mathrm{~m}$ to $3.75 \mathrm{~m}$ (8' to 12'). Buried organic material was collected for radiocarbon dating to discover when the humus layer was 
formed and to provide a record concerning the past history, climate, and soil structure of the lobe. I tried to have samples dated at the University of Washington but they advised me that the samples did not contain enough organic matter to do so.

Soil samples were collected from within the terraces and laboratory tested för texture analysis. Soil colors were taken using the Munsell soil chart (1954). Four soil samples were taken from within terraces at Maiden Peak and two samples from within terraces at Gray Wolf:

Measurements of downslope movement were made to determine if present conditions allow the terraces to be active, and to determine the rate of movement. The method employed was the use of painted in situ (in place) rocks, and measurements were made from a point of bedrock to the painted rock.

I had no adequate equipment with which to make climatic measurements and little data are available from other sources. During the summer of $1975,65 \%$ of the days were either of rain or drizzling fog. Conditions for field work were far from ideal, cold and dampness permeating everything. 


\section{CHAPTER V}

\section{TERRACE DISTRIBUTION AND DESCRIPTION}

Turf-banked terraces are found on 12 to 24 degree convex to concave slopes, and are best-developed on the gentler areas on the slopes. Nevertheless, the terraces flow in the direction of the steepest available slope.

Terraces are not found on the flat tops of ridge saddles. Studies indicate that a slope of 3-4 degrees is considered the lower limit for terrace development, and they seem to be best developed on slopes of 5-20 degrees (Jahn, 1960, p. 56; Dutkiewicz, 1961; p. 285; Price, 1972, p. 37)。

Terraces are found developed above the treeline of $1725 \mathrm{~m}$ ( $5750^{\circ}$ ), however, where treeline is advancing upslope, inactive terraces appear below the present limit of trees. Slopes with almost total alpine vegetative cover have well-developed terraces, while slopes lacking in alpine vegetation have no terrace development.

Although found on several upland slopes, the formation of terraces is most extensive at Maiden Peak and at the Gray Wolf Cirque (Figure 8): Terraces occur within the range of $1725^{\mathrm{m}}$ and $1860 \mathrm{~m}$ (5750 and 6200') at Maiden Peak and between $1725 \mathrm{~m}$ and $1950 \mathrm{~m}$ (5750' and 6500') at Gray Wolf. 
Terraces at both Maiden Peak and Gray Wolf are most extensively developed on the eastern ridge of a north-facing cirque. Terraces at Maiden Peak cover $80 \%$ of a slope with a gradient of $12^{\circ}$, of a slope with a gradient of $15^{\circ}$, and of a slope with a gradient of $24^{\circ}$. Terraces at Gray Wolf cover $70 \%$ of a slope with a gradient of $22^{\circ}$, and of two slopes with gradients of $15^{\circ}$.

Generally the terraces move in the direction of the steepest slope available, however, snow accumulation influences the direction of movement. Snow accumulates on the leeward side of the terrace, and the soil will move toward the snow, often at an angle to the slope. Terraces move at an angle to the slope on the northeast-facing slope at Maiden Peak and on the northwest-facing slope at Gray Wols.

Single lobes frequently encroach upon each other forming a number of "stair-steps" down the slope, a few of the larger lobes being formed by the coalescing of smaller lobes. Often the terraces join together in a crenuate necklace like fashion lateraliy across the slope. The length of these joined scalloped fronts may be several score long.

The heights of terrace risers and the lengths of terrace treads of twelve lobes on three slopes at Maiden Peak and of four lobes at Gray Wolf are given in Table II. The lobes measured are mapped by number on Figures 15 and 16. 


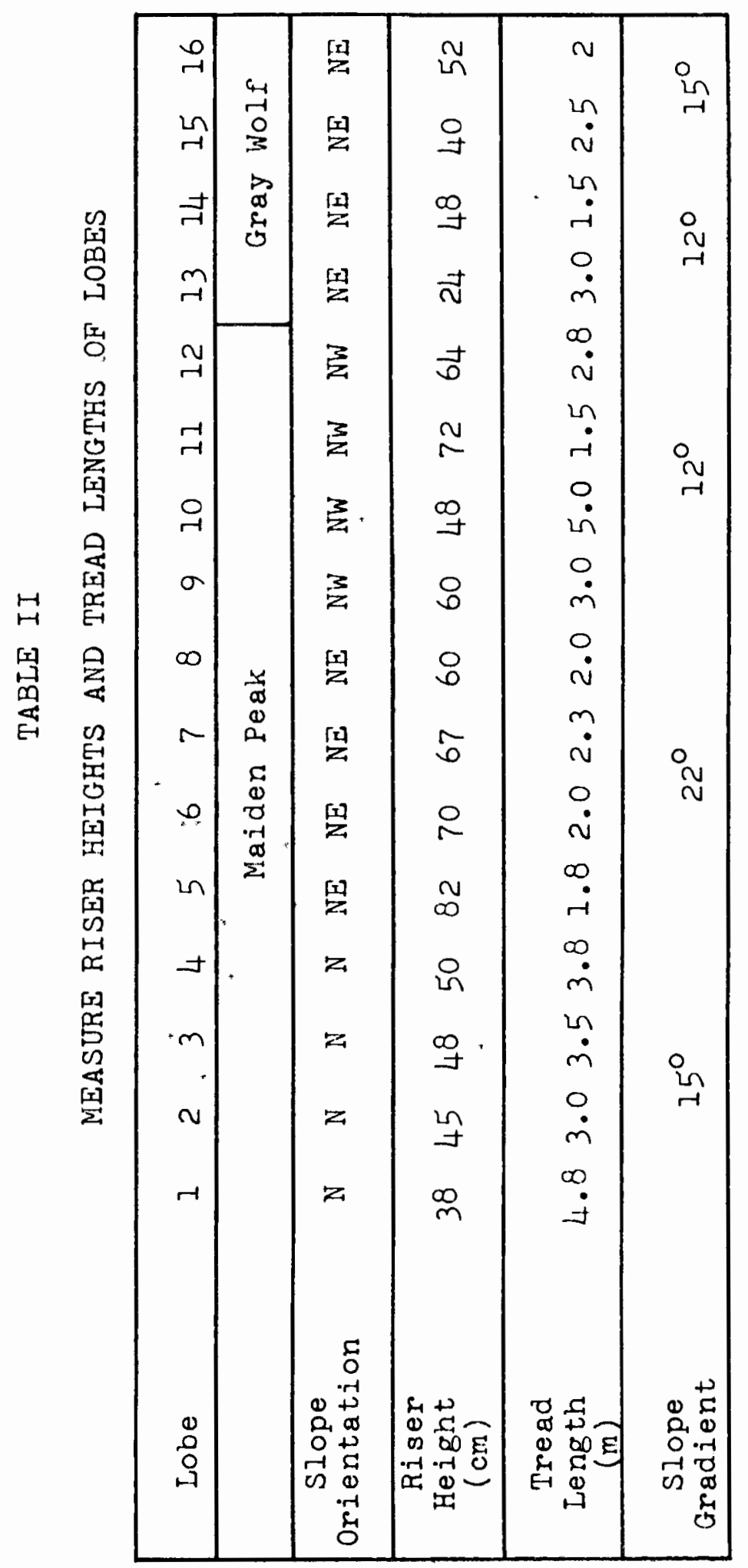




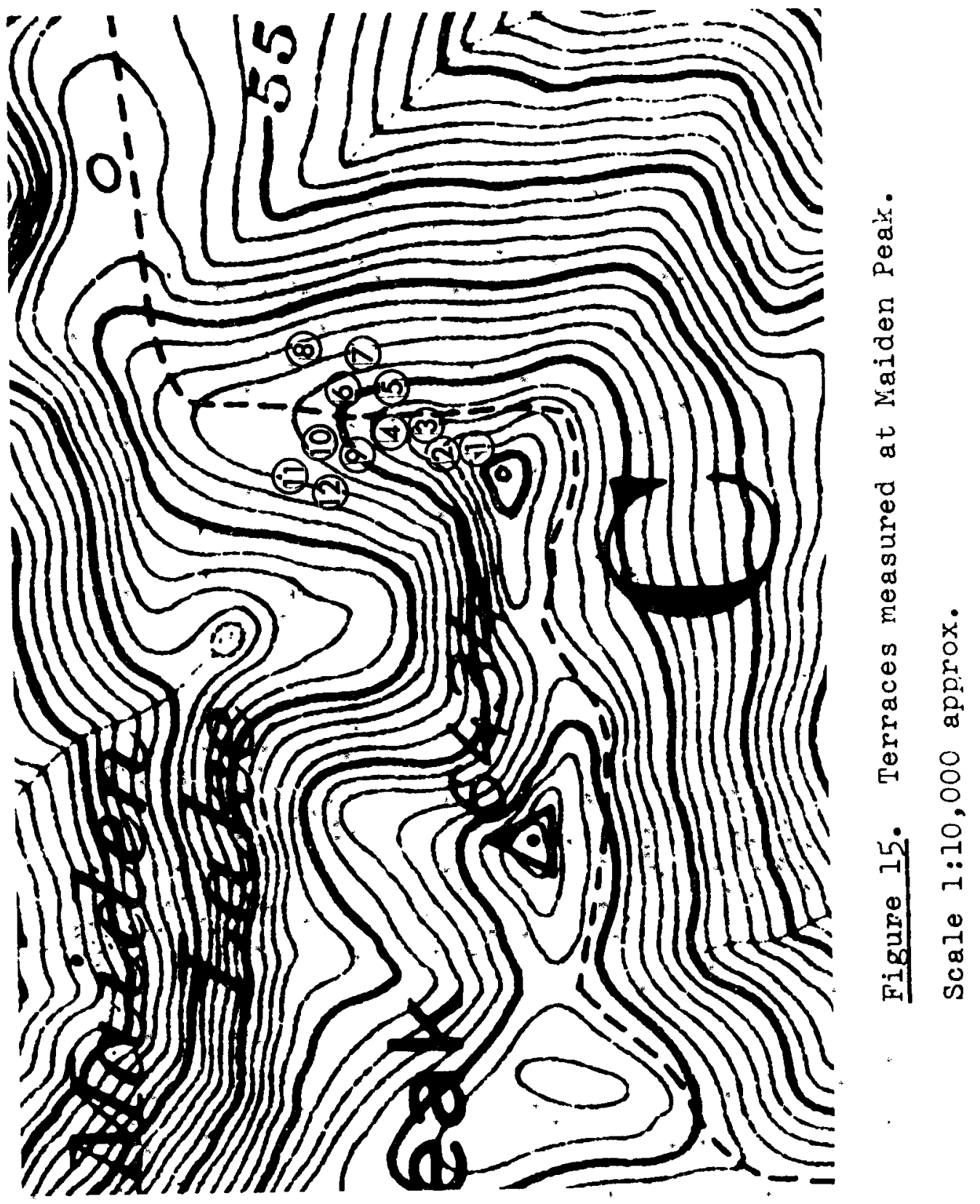




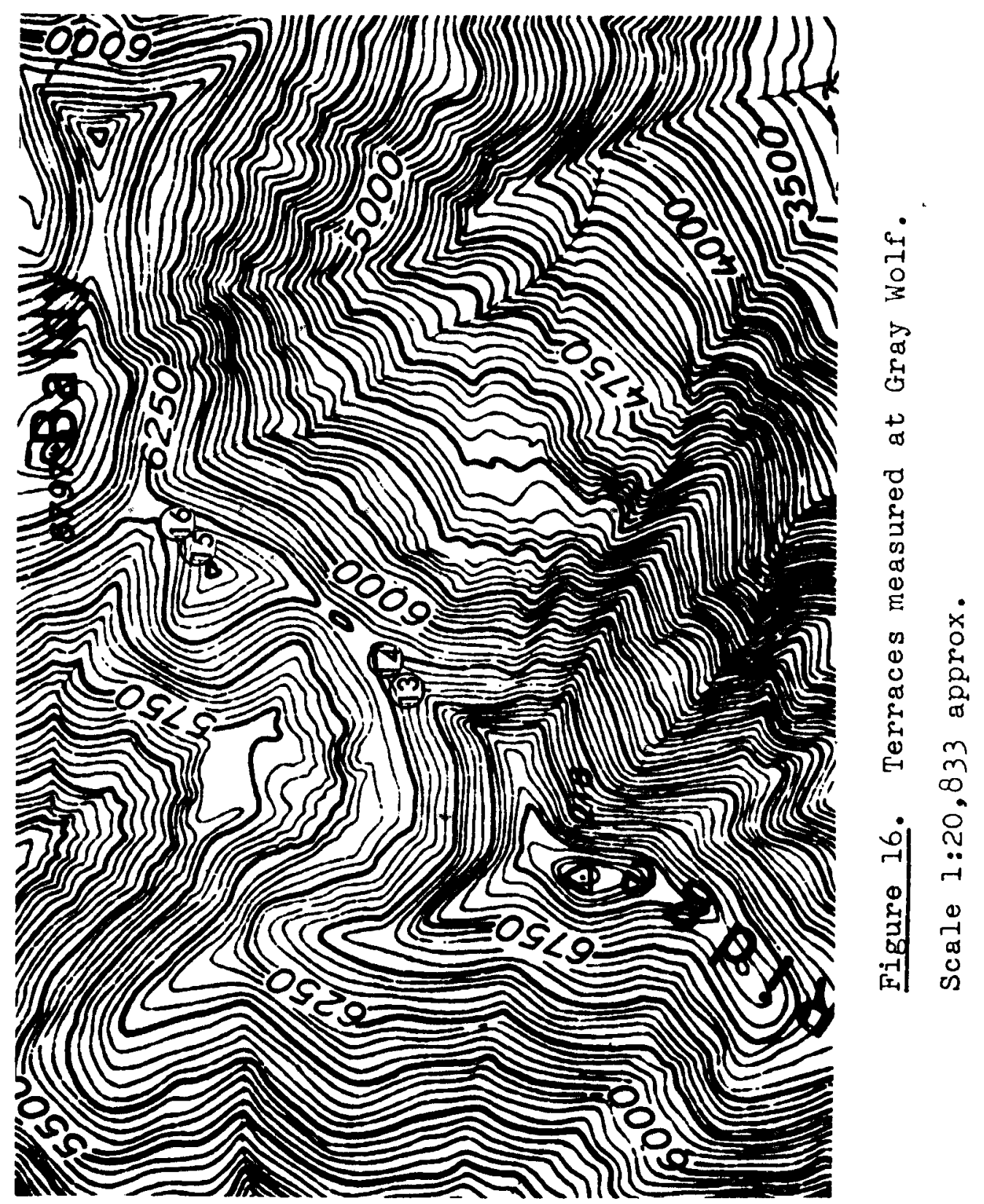


The average height of the terrace risers is $55 \mathrm{~cm}$ but they vary from $38 \mathrm{~cm}$ to $82 \mathrm{~cm}$. The average length of the terrace tread is $2.7 \mathrm{~m}$ and vary from $1.5 \mathrm{~m}$ to $5.0 \mathrm{~m}$. Terraces at Maiden Peak are more developed in form and height than the terraces at Gray Wolf, perhaps indicating different stages in the development of the terraces. As a general rule, the tread length decreases as the slope gradient increases, while the height of the riser often increases with increased slope gradient. The treads lie at a small angle (3-7 degrees) to the horizontal, less steeply inolined than the general slopes. Many of the larger risers bulge outwards, and in some cases I was able to insert: my hand horizontally under the riser up to $23 \mathrm{~cm}$ (9")。

Frost boils occur on the treads of many terraces. These are bare soll patches, commonly circular, commonly polygonal, or commonly amorphous in shape. Some of these have large cobble-size shafe fragments occurring around their outer edges, finer fragments towards the center, and the finest material in the center, like sorted stone rings (Washburn, 1956). The soil is moist and the presence of nubbins indicates frost stirring. .

Sorted stone stripes occur on the upper, west-facing slope of the saddle at Maiden Peak and on the north-facing slope at Gray Wolf. The stripes trend in the direction of 
the steepest slope and are distinguished by alternating rows of vegetation-covered and vegetation-free ground. The stone stripes are approximately $30 \mathrm{~m}$ (1001) long. Below the stripes turf-banked terraces develop as a result of water, channeled downslope by the stone stripes, to soil less exposed to wind erosion.

On west and southwest facing slopes, high exposure to solar radiation, high winds, and the presence of rocky scree slopes, result in little vegetation. The plant life is often in elongated stripes running downhill with stone stripes between. Common alpine species include Phlox diffusa, Arenaria obtusiloba, Draba lanchocarpa, Synthyris lanuginosa, Carex albonigra, Potentilla diversifolia, and Luplnus lepidus (Bliss, 1969, p. 174). North and northeast facing slopes provide a milder climate with late lying snowbanks, shade, and wind protection. Plant life here is richer but it must contend with unstable soils. Dominant species include Arenaria capillaris, Antennaria lanta, Carex spectabilis, Lupinus latifolius, Polygonum bistortoides, Phlox diffuse, and Festuca idahoensis. 
CHAPTER VI

VEGETATION

A quadrat size of $20 \mathrm{~cm}$ by $50 \mathrm{~cm}$ (7.9" by 19.7") was used to sample vegetation with the long axis oriented upslope at $1.5 \mathrm{~m}\left(5^{\prime}\right)$ intervals. Species were sampled for abundance, frequency, and percent cover; in order to obtain an importance value of the speoies and to determine species dominance in any one area. Species were identified in the field with help from Dr. Richard Fonda of Western Washington state College.

Abundance is a measure of the number of plants of an individual species occurring within a quadrat. Those species which contain several shoots from one rhizome were counted as one plant. These include: Iupinus latifolius, Iupinus lepidus, Festuca idahoensis, Fescue sandwort, Juncus dramondil, and Phlox diffusa. Percentage cover is the percent of area within each quadrat that each species occupied. Percentage cover was also estimated for moss, 1ichens, duff, and bare ground. Frequency is the number of quadrats in which each species occurred compared to the total number of quadrats sampled at a site: 


$$
\text { Frequenoy }=\frac{\text { \# of quadrats where species occurs }}{\text { total \# of quadrats sampled }}
$$

To achieve an overall view, abundance of vegetation and percent cover were calculated. for the entire transect (Frequency, by the nature of its calculation, is already done for the entire transect), by the following formulas:

$$
\text { Total relative abundance }=\frac{\text { Total \#'s of individuals }}{\text { Total \# of species }}
$$

Total relative cover $=\frac{\text { Total coverage of individual species }}{\text { Total area of all quadrats }}$

Total relative frequency, total relative coverage, and total relative abundance were then added together to produce a summation index. The magnitude of this index is a good indication of the vegetational importance of a species i.e:: relative importance value, (Curtis and McIntosh, 1951; p. 482)。

Relative importance values were added together for each species in all four transects and divided by four to produce a total importance value. This value provides a macro-view of the enviranment of the turf-banked terraces. Relative importance value of species for each transect and their total importance value for the two study areas, are Iisted in Table III.

An analysis of the importance values for all species shows that only a few achieve dominance in any area. 
TABLE III.

SPECIES AND THEIR RELATIVE AND TOTAL IMPORTANCE VALUE

\begin{tabular}{|c|c|c|c|c|c|}
\hline . & \multicolumn{3}{|c|}{$\begin{array}{l}\text { Relativé } \\
\text { Importance } \\
\text { Values for } \\
\text { Individual } \\
\text { Transects }\end{array}$} & & $\begin{array}{l}\text { Total } \\
\text { Relative } \\
\text { Importance } \\
\text { Values. } \\
\text { In percent }\end{array}$ \\
\hline $\begin{array}{c}\text { Genus species } \\
\text { Achillea millefolium }\end{array}$ & 77 & 68 & & & \\
\hline \multirow{2}{*}{$\begin{array}{l}\text { Antennaria lanta } \\
\text { Arenaria capillaris }\end{array}$} & 47 & 13 & 107 & 177 & 86 \\
\hline & 87 & 86 & & & 43 \\
\hline Artemesia suksdorfii & 56 & 12 & & & 7 \\
\hline \multirow{2}{*}{$\begin{array}{l}\text { Carex phaeocephala } \\
\text { Cetraia islandica }\end{array}$} & & & 44 & & \\
\hline & & 20 & $\begin{array}{l}20 \\
50\end{array}$ & & 10 \\
\hline $\begin{array}{l}\text { Douglasia laevigata } \\
\text { Erigeron peregrinus } \\
\text { Erigeron trifidus }\end{array}$ & 22 & & & . & +6 \\
\hline Erigeron trifidus & 22 & & & & \\
\hline $\begin{array}{l}\text { Festuca idahoensis } \\
\text { Heracleum lanatum }\end{array}$ & $\begin{array}{l}71 \\
31\end{array}$ & 100 & 74 & 122 & $\begin{array}{r}92 \\
8\end{array}$ \\
\hline Juncus dramondii & 34 & & & & 9 \\
\hline \multirow[b]{2}{*}{ Licopedum } & & & 88 & & 22 \\
\hline & 35 & & 109 & & 36 \\
\hline Lupinus latifolius & 120 & 24 & & 21 & $\begin{array}{l}30 \\
11\end{array}$ \\
\hline \multirow{2}{*}{ Phlox diffusa } & & 130 & 95 & 115 & 85 \\
\hline & 75 & 90 & 50 & 84 & 75 \\
\hline $\begin{array}{l}\text { Potentilla diversifolia } \\
\text { Silene parri }\end{array}$ & 10 & $\begin{array}{l}79 \\
76\end{array}$ & & 21 & $\begin{array}{r}5 \\
25 \\
19\end{array}$ \\
\hline \multirow{2}{*}{$\begin{array}{l}\text { Veronica cusickii } \\
\text { Lichens }\end{array}$} & $c$ & & & 133 & 40 \\
\hline & 43 & 162 & 304 & 86 & 150 \\
\hline $\begin{array}{l}\text { Bareground } \\
\text { Duff }\end{array}$ & 95 & & $\begin{array}{l}58 \\
14\end{array}$ & 230 & $\begin{array}{r}96 \\
5\end{array}$ \\
\hline
\end{tabular}


The highest values are for Carex spectab1lis, Festuca idahoensis, Phlox diffusa, Antennaria lanta, lichens, and bareground, (Table III). Carex spectabilis is the dominant species immediately below the lobe riser where soil is moist and the most protection is afforded. It appears to be the most competitive species and best adapted to conditions in that microenvironment. "Iichens dominate on the riser where, exposed to solar radiation and wind dessication, conditions are the harshest. Where plants cannot withstand the instability of the soil and the dessication, only bare ground exists. Festuca idahoensis, Phlox diffusa, and Antennaria lanta have high importance values because they are fairly cosmopolitan, having no particular site preference.

\section{VEGETATION COMMUNITIES}

Plants are distributed along environmental gradients according to soil type, moisture availability, and topography. If the gradient is steep, the selective environmental forces will produce abrupt changes in species composition. If the gradient is gentle, a cline or continum exists, and it may be difficult to recognize changes.

Three plant communities can be recognized across the solifluction terraces. I have labeled these: Late Snowbank, Tread, and Riser communties. The tolerance range of each species may overlap that of other species, but the range 
of optimum development for each is different from that of all other species. In the alpine area many factors are limiting to life, and microtopographic changes allow different species to occupy different sites. The vegetation is thickest immediately below the risers and thinnest on the tread.

\section{SNOWBANK COMMUNITY}

The Snowbank Community is, located immediately downslope from the riser. Other authors have found a similar community, including Billings and Mark (1961), Johnson and Billings (1962), and Price (1971a). The distance downslope from the riser in which the late Snowbank Community exists averages $61 \mathrm{~cm}\left(24^{\text {in }}\right)$. The width varies with the height of the lobes; the higher the riser, the wider the community. The exeeption occurs when the riser becomes high enough to enable considerable snow to accumulate; this may have a reverse (deleterious) effect on vegetation. If the snow does not melt until late summer, the vegetation does not have enough time to complete its growth cycle and is destroyed (Price, 1971a, p. 640). This is not yet happening to the terraces in the 0lympics because the riser height is usualiy less than $I \mathrm{~m}$ (31). The plants occurring in the Snowbank Community are generally less droughtresistant than those occupying the lobe treads. The zone 
Immediately below the riser is the most protected and moist of the various habitats for the following reasons: 1). the overhanging risers protect the area from dessicating winds, 2) the area has a low angle of incidence of solar radiation so that temperature variations are relatively less extreme, and 3) snow collects in this microhabitat providing insulation dưring winter, as well as providing water late into the spring.

Dominant plant species in the Snowbank Community include Carex spectabilis, Festuca idahoensis, and Polygonum bistortoides. Species of less abundance are Veronica cusickii, Lupinus latifolius, Leutka pectinata, Solidago multiradiata, Carex phaeocephala, Potentilla diversifolia, Heracleum lanatum, and Erigeron peregrinus (Figure 17).

\section{TREAD COMMUNITY}

Downslope from the Snowbank Community, physical conditions become harsher because of increased exposure. This is the Tread Community or mesic-grass type of Kuramoto and Bliss. These authors suggest that the plants in the community are remnants of the hypsithermal: "Oommunities such as those in the 0lympics probably are remnants of a once widespread vegetation that has become isolated in ocologically suitable habitats on mountain tops" (Kuramoto and Bliss, 1970, p. 325). Species Include Festuca idahoensis. 


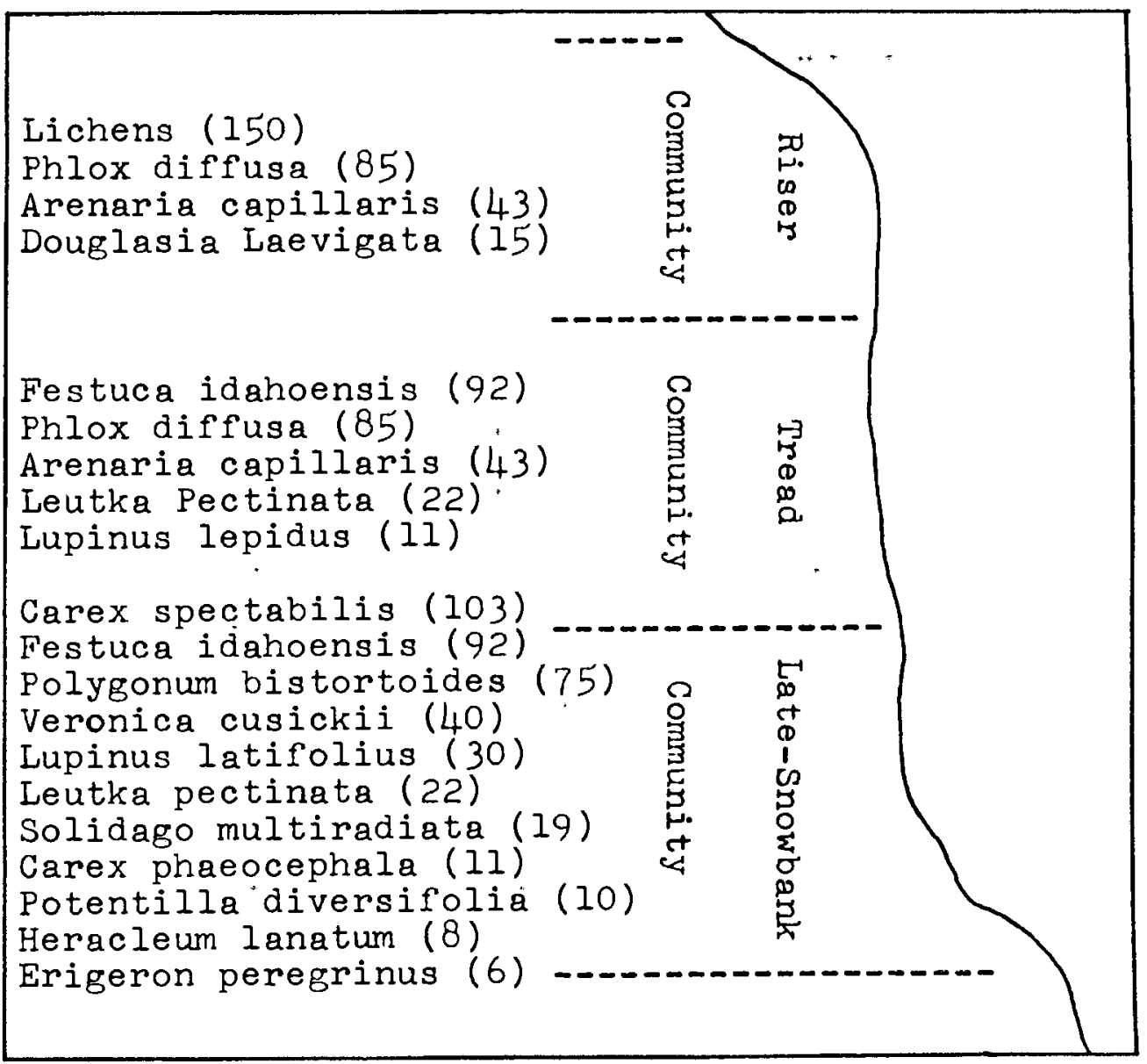

Figure 17. Distribution of species and their importance values within communities across a turf-banked terrace. 
Phlox diffusa, Arenaria capillaris, Leutka pectinata, and Lupinus lepidus (Figure 17). Active frost boils are common in the tread zone. Enough water is provided by snowmelt to keep needle ice active in early summer and thus the soil is extremely unstable. Only Lupinus lepidus appears able to withstand such rigorous conditions.

IV. RISER COMMUNITY

On the riser or frontal bank of the lobe is the Riser Community. Here the dessicating winds free the soil of snow early in spring, soil drainage is relatively'good, and there is a high angle of solar radiation thus producing the harshest microenvironment on the lobe. Lichens cover almost the entire area and include: Cladonia ssp., Cetraia islandica, and Thamnolia vermiculatus. In less abundance, low, matmforming and semi-woody species, Phlox diffusa, Arenaria capillaris, and Douglasia laevigata occur here (Figure 17). In comparison with vegetational studies across slopes with solifluction lobes in other areas (Billings and Mark, 1961; Price, 1971a) the plant communities on the lobes in the study site are much less sharply delineated. This may be because they are smaller. On surfaces experiencing solifluction and frost-heaving conditions are severe for vegetation for two major reasons: 1) because of the movement and instability of the substrate, 
and 2) because of the lack of moisture which occurs towards the end of summer. The vegetation on solifluction terraces grows and develops while the soil is in motion. Thus the structure and patterns of vegetation are influenced by the intensity and type of movement. Frost action, especially needle ice activity, damages roots and stems by uplifting and.stretching them. Solifluction often buries existing plants, changes soil-water relations by moving plants with respect to the water table, and causes deformation of stems. Along the sides and on the faces of the terraces I found the underground stems of woody plants extending upslope: This indicates that the plants, while growing, have been pushed downslope as growth continues.

Seidenfaden (1931) studied moving soils in East Greenland and found that "very few flowers occur because the plants have to use all of their energy just to stay alive. Digging below these plants one will see that the subsoil is largely made of the dead shoots of these species. The solifluction must thus be so considerable that the plants have to use all its force to keep the vegetative organs in the light", (Seidenfaden, 1931, p. 5). The soil movement of the turf-banked terraces I studied is not that violent; all species bloomed during my fleld investigation, and the subsoil did not contain a large amount of dead shoots. The vegetation on these alpine slopes has a riciprocal effect since it, in turn, influences the development of the turf-banked terraces. A tight mat of toots and stems 
produces an insulating effect which guards against extreme temperatures, prevents dessication, retards runoff, and thus promotes high soil moisture values. When the soil becomes saturated and begins to flow, its movement is only partially checked by the vegetation. It appears that the additional moisture contributed by the vegetation more than compensates for its binding effect. Price (1972, p. 38) believes that insulation by vegetation in permafrost areas is more important than retardation of movement, because vegetation and solifluction are frequently best developed in the same sites - the wetter areas. This holds also true for the olympics, where the drier slopes (e.g., south-facing slopes) have only sparse vegetation and no solifluction, while solifluction and vegetation are best developed on the moister, north-facing slopes. Cirque areas, which are still undergoing active mechanical erosion, and have steep headwalls which hinder soll development; moisture collection, and vegetational growth, do not have terrace development. 
CHAPTER VII

LOBE EXCAVATIONS

I. LOBE \#3

The first terrace excavated was oriented 5 degrees east of north on a 15 degree slope of Maiden Peak (Table II and Figure 15). A trench $3 \mathrm{~m}$ (10') long, $1 \mathrm{~m}$ (3') wide, and $.5 \mathrm{~m}$ ( 1 1.2') deep was dug through the terrace from the uppermost part of the platform to the lower edige of the riser (Figure 18). The surface was totally vegetated and tightly bound together by a thickly matted, fine root system. The surface humus layer was $41 / 2 \mathrm{~cm}$ to $151 / 2 \mathrm{~cm}$ (2 1/2" to 6") thick. Beneath the humus layer a lighter horizon (1OYR/5/3) of mineral soil existed. The lighter horizon, largely composed of small interstitial fines and small tabular stones, thinned towards the back of the platform, $1 \mathrm{~cm}$ to $61 / 2 \mathrm{~cm}$ ( $1 / 2^{\prime \prime}$ to $\left.21 / 2^{\prime \prime}\right)$, yet was very thick, $23 \mathrm{~cm}\left(9^{\prime \prime}\right)$, close to the riser front (Figure 18). This is a strong indication that the soil in this layer was or had been moving. The flow was halted at the riser front by the vegetation and a soil build-up occurred forming a turf-banked terrace. Beneath this lighter mineral soil layer, a dark brown (10YR/3/3 layer exists (Figure 18). I 


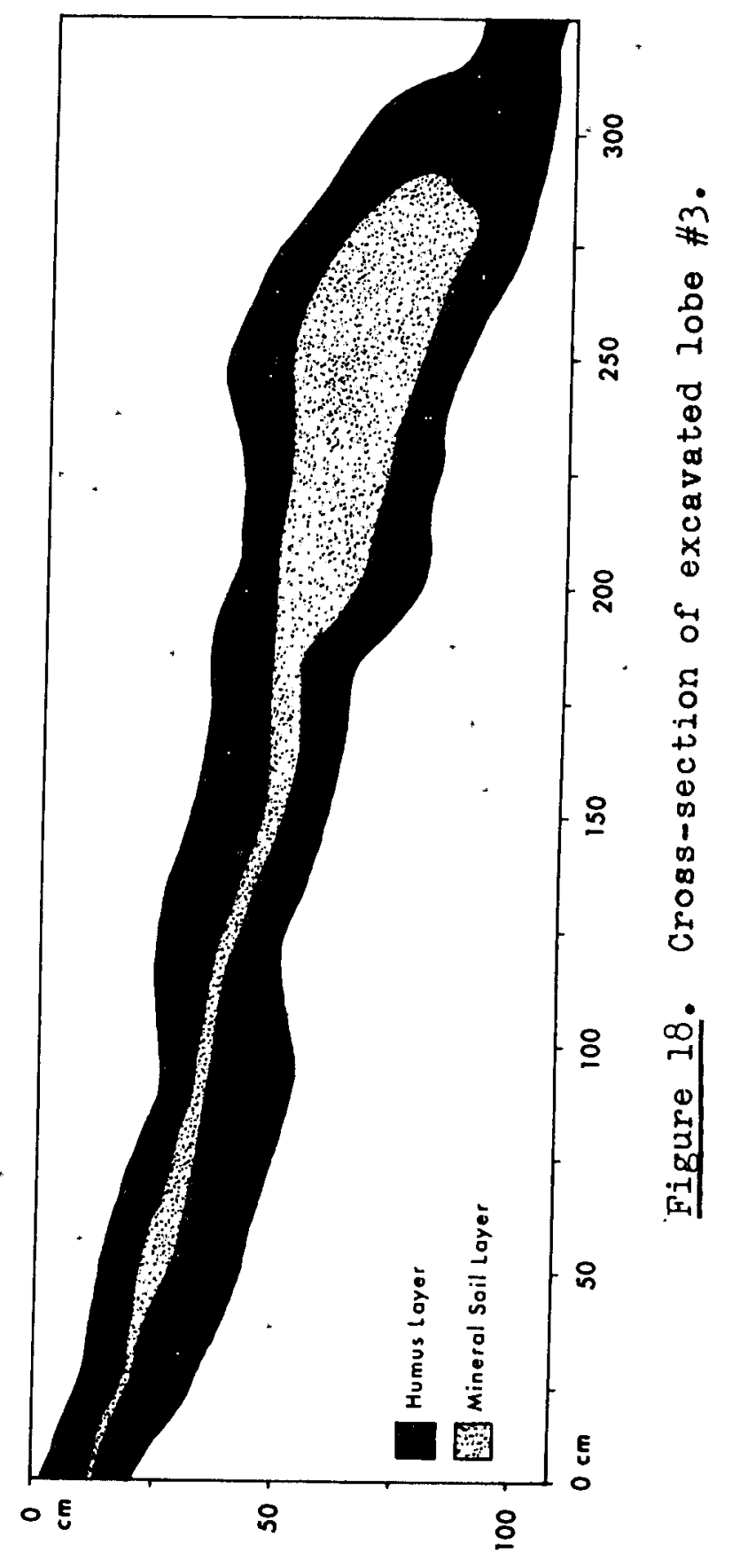


assume this buried organic horizon to be the former vegetated surface. When the upper layer became saturated and began to flow it overrode the vegetated surface. The lower humus layer within this lobe become increasingly decomposed farther into the terrace. The decomposed nature of the humus indicates that the downslope movement of the terrace has been gradual: Below the organic layer is a horizon of unconsolidated weathered sandstone and slate.

Buried organic material.within lobes has been widely reported in solifluction areas by Washburn (1947), Sigafoos (1951), Sigafoos and Hopkins (1952), Wilson (7952), Williams (1957), Johnson and Billings (1962), and Price (1970). Drow and Shanks (1965, p. 289) found occasional buried surface horizons (organic layers) which they believed to serve as a source of plant nutrients for the existing vegetation. Rudberg (1958) believes the humus layers interspersed with mineral soil indicated movement in stages. Several authors have described inverted soil profiles directly overlying normal profiles, reflecting "rolling over" of the lobe or terrace front (Washburn, 1947; Tro11, 1958; and Benedict, 1970). In other cases, there is a suggestion that shearing has occurred (Drury, 1962; Benedict, 1970; and Price, 1970).

Drury (1962, p. 16) found fresh deposits which show a small delta of mud built out over previous years' 
vegetation in many places on the surface of terraces. This was not observed in the Olympics.

Angularity of rock fragments within the solifluction deposits is characteristic since they have not traveled far. I found that the stones are oriented in the direction of movement with their longitudinal axis pointing downslope and their flat surfaces parallel to the lobe surface. Many authors have found similar stone orientations, including Iundquist (1949) and Cailleux (1950).

\section{LOBE \#10}

A second terrace excavated was on the northwestfacing slope with a gradient of $12^{\circ}$ at Maiden Peak (Table II and on Figure 15). A trench was dug $4 \mathrm{~m}$ (12') 1ong, $1.2 \mathrm{~m}$ (4') wide, and $1 \mathrm{~m}$ ( $3^{\prime}$ ) deep. The soil layers were not well-defined within the terrace cross-section, although slight differentiations were discerned (Figure 19). All the horizons appeared to be very hummocky, indicating soil movements, and quite rocky.

The terrace was entirely vegetated and had produced a surface humus layer $5 \mathrm{~cm}$ to $20 \mathrm{~cm}$ (2" to $8^{\prime \prime}$ ) thick. Beneath this layer was a light brown (1OYR/5/4) horizon of mineral soil and then an ashy grey podzolic layer (10YR/5/3). Many fine, thickly matted roots extended through these three layers. Below the grey horizon, orange (7.5YR/4/4) to reddish-brown (10YR/4/3) horizons existed. 


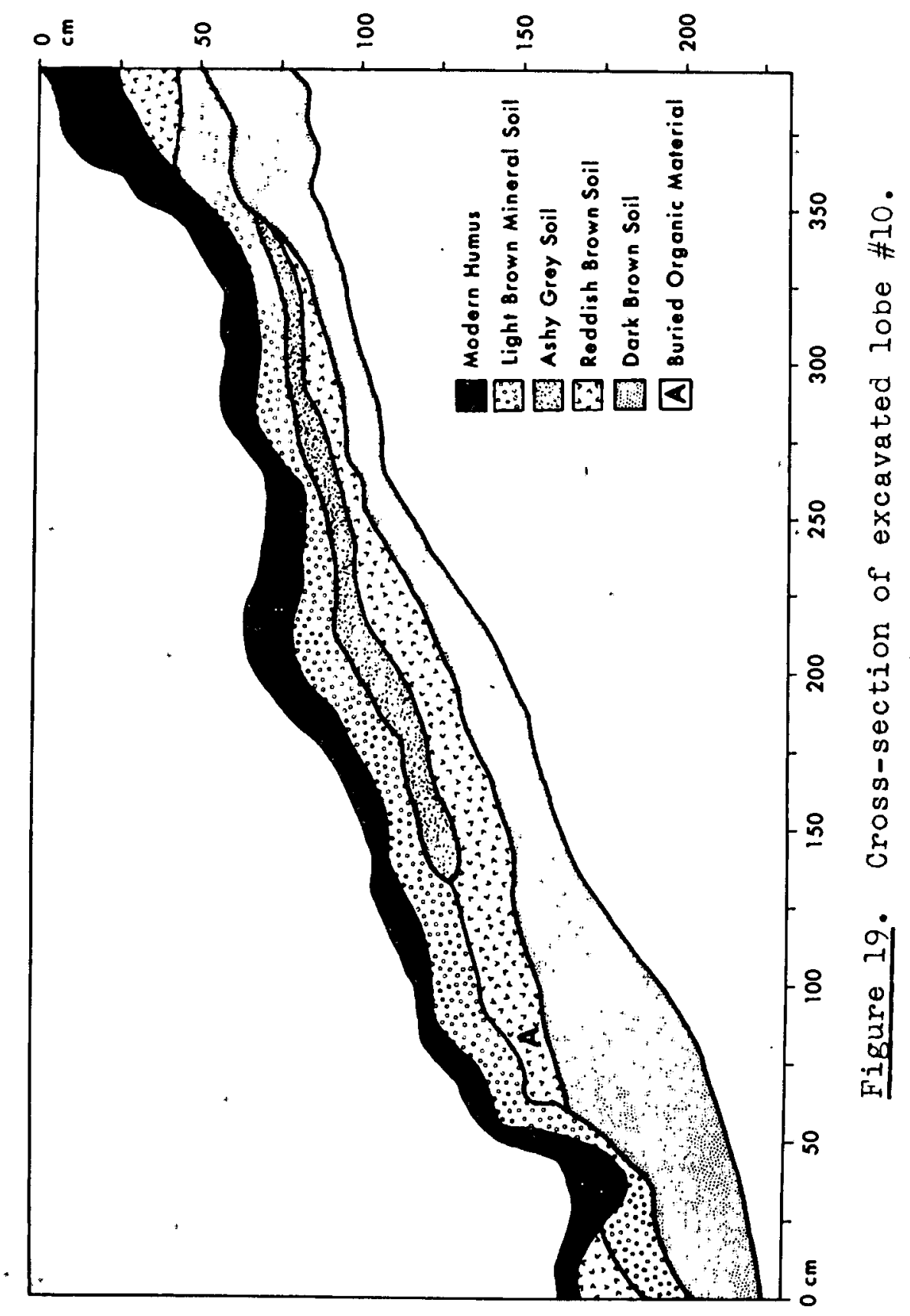


The soil became darker with depth until a dark-brown (10YR/3/4) rocky layer was reached. From the orange horizon downward the soll becomes progressively more rocky. At point 'A' within the terrace, a small spot, $5 \mathrm{~cm}$ by $5 \mathrm{~cm}$ ( 2 " by $2^{\prime \prime}$ ) was very black, appearing carbon-like when smeared on my hand. Perhaps this was a piece of wood buried during terrace formation.

The absence of a buried humus layer implies that a vegetated horizon was not present on the slope prior to lobe formation or that the soil movement has taken place under the vegetated surface, moving downslope without distarbing the plant cover rather than the "rolling over" type of movement which would cover and bury pre-existing vegetation. Whatever the case, there is no buried humus layer.

\section{LOBE \#15}

A third terrace was excavated on a northeast-facing slope of $15^{\circ}$ near the Gray Wolf cirque (Table II and on Figure 16). The trench dug was $3 \mathrm{~m}$ (9') long, $1 \mathrm{~m}$ (3') deep, and $.3 \mathrm{~m}$ ( $\mathrm{I}^{\prime}$ ) wide. The lobe tread was completely vegetated with grasses, lichens, and thickly matted cushion plants. Below the vegetation a humus layer had developed, tightly bound by extensive, fine roots (Figure 20). This humus horizon was between $61 / 2 \mathrm{~cm}$ and $13 \mathrm{~cm}$ (2 $1 / 2^{\prime \prime}$ and $\left.5^{\prime \prime}\right)$ thick. Beneath the humus layer the mineral soil 


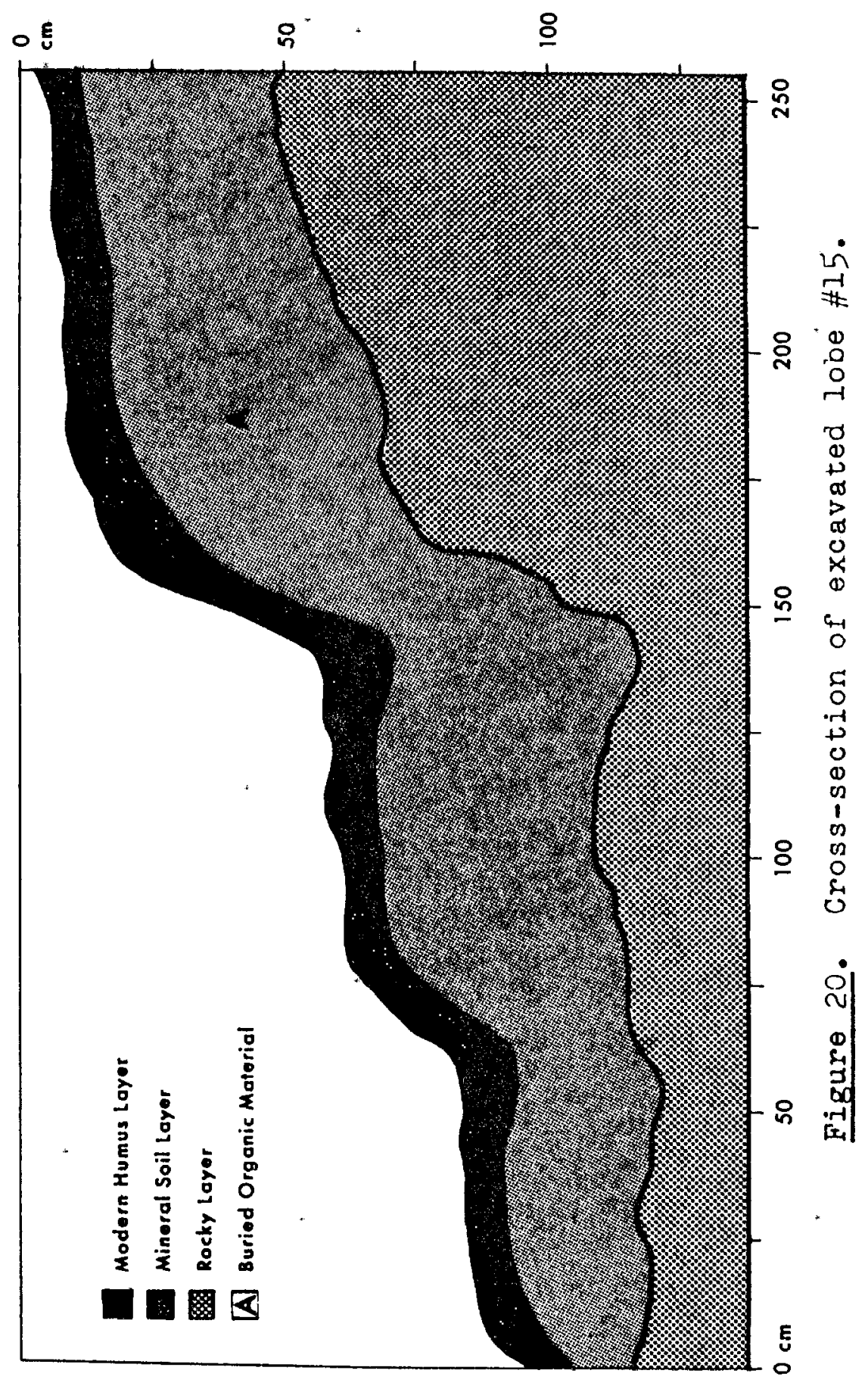


was lighter brown $(10 Y R / 5 / 4)$ but horizons within the soil were not well defined. This layer ranged from $21 \mathrm{~cm}$ to $46 \mathrm{~cm}$ (6" to $18 ")$. There was one small area, $5 \mathrm{~cm}$ by $10 \mathrm{~cm}$ ( 2 " by $4^{\prime \prime}$ ) of dark organic matter at point 'A' (Figure 20). The origin of this organic material may have been an animal's nest. Below the layer of mineral soil a rocky horizon existed of cobble-sized sandstone and slate fragments.

The lack of a buried organic layer may indicate that plants did not exist before the formation of the turfbanked terrace, or that the soil is flowing under the skin of vegetation rather than rolling over it. It is speculated that because there is such a large soil build-up the soil may have been, wind deposited. The source of this soil, with, its fine texture may be glacial flour, or perhaps it was produced during the weathering of Gray Wolf cirque. If the soil is aeolian, it indioates this slope is somewhat protected from winds. Lobes do not occur on south-facing slopes wherewinds abrade. When the soils of this excavation were laboratory tested, however, the material proved to not be fine-textured enough to be of aeolian origin. 
CHAPTER VIII

\section{SOILS}

\section{SOIL DESCRIPTION}

The Gray Wolf soils were a dark yellowish-brown (10YR/3/4) in color, while those from Maiden Peak were a dark grayish-brown $(20 Y R / 4 / 2)$ in color. This color difference is an indication that there is more organic matter in the soils of Maiden Peak than in the soils of Gray Wolf. Tiny rootlets penetrated throughout almost all the soil layers and the soil samples had numerous rock fragments and pebbles of slate and sandstone. The pebbles give a loose structure to the soil, facilitating water movement. The sandy soils by themselves lack the capacity to absorb and hold moisture, however, organic matter, especially roots, acts not only as a binding agent for the particles but also increases the water-holding capacity of the soil. The structure of the soils is also aided by the presence of silt and clay. Silt and clay, together composing $40 \%$ of the soils, give the soil a higher capacity to retain water and a greater ability to flow. Silt is more subject to flow than clay because it lacks the cohesion of clay and slakes readily. The percentage of clay in the soil samples, being only $20 \%$, does not 
greatly inhibit water movement through the soil.

Water conducts well through the sandy loam soils because of their loose structure aided by many pebbles. However, the organic matter, roots, silt, and clay allow the soil an adequate amount of water retention.

The soils are moist, protected from dessication by a fairly complete cover of vegetation. The most important source of soil moisture for terrace development are the protected late-lying snowbanks which provide meltwater into early summer. The soil is wettest below areas of snowbank accumulation and becomesdrier with increased distance downslope. Late-lying snowbanks at Maiden Peak were found on the north-facing slope directly below the mountain peak and on the east-facing slope. During 1975, the snowbanks lasted until July 10. During the melting of the late snowbank on the north-facing slope the soil was so saturated we sank to ankle deep in it and the disrupted soil began to flow downslope (Figure 2l).

Ground ice withdraws water from the deeper soil horizons and produces a concentration of water in the uppermost layers. Needle ice growth is seen frequently within the frost boils on the terrace treads. Rain, fog drip, and ground ice contribute moisture; because of winds and solar radiation, however, the actual effective mositure contributed is slight. 


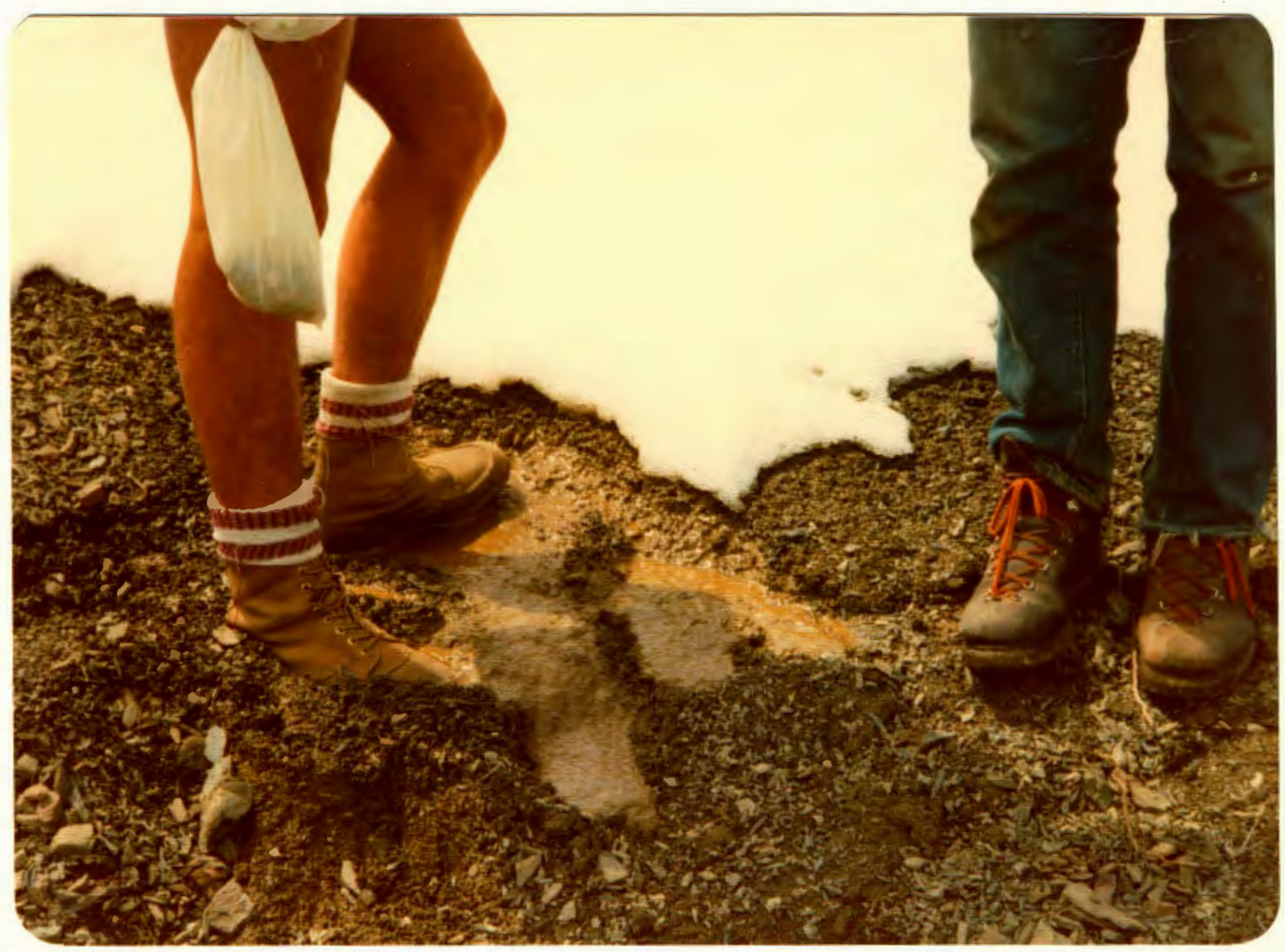

$\frac{\text { Figure 2l. }}{\text { snowbank. }}$ Saturated soil below a late-lying

\section{LABORATORY TESTS}

Soil texture determines the water-holding capacity and permeability of the soil, and thus influences the saturation point necessary for solifluction. Six soil samples were collected during the excavation of terraces; two samples at Gray Wolf and four samples at Maiden Peak. The soils were laboratory tested for soil texture using the Bouyoucos Mechanical Analysis of Soils by the Hydrometer Method (Bouyoucus, 1936). 
The soils were first sifted to remove all rocks, pebbles, and debris larger than $1.0 \mathrm{~mm}$. Humus was removed by saturating the soils with water and allowing organic matter to float to the top where it was strained off. The soil was then oven-dried and $50 \mathrm{gms}$ of each sample weighed for testing purposes. Water and $10 \mathrm{cc}$ of Calgon were added to the soils in a jar and the samples were put in the shaker for 1 hour to allow dispersion. The samples were then poured into $1205 \mathrm{ml}$ cylinders with water at $67^{\circ} \mathrm{F}$ and the cylinders were shaken by hand for one minute. The cylinders were then set on the table and a hydrometer immediately placed into the cylinder.

The hydrometer reading at the end of 40 seconds was divided by the amount of absolute dry soils taken (50 gms) and multiplied by 100 . The result was the percentage of material still in suspension at the end of 40 seconds. This percentage was subtracted from 100, the result being the amount of sand $(1.0-0.05 \mathrm{~mm})$ in the soil. The hydrometer reading at the end of 1 hour was divided by the weight of the soil sample ( $50 \mathrm{gms}$ ) and multiplied by 100 . The result is the percentage of material still in suspension and is considered to be the conventional clay $(.005-.000 \mathrm{~mm})$. The percentage of the silt $(.05-.005 \mathrm{~mm})$ was obtained by subtracting the clay from 100, and from this result, subtracting again the percentage of sand. 
To check the measurements made by the Hydrometer Method, I sifted $50 \mathrm{gms}$ of each soil sample through a $.05 \mathrm{~mm}$ sieve. The sand in the soil, unable to go through the sieve openings was then weighed. The percentage of sand in 50 gms of soil was then calculated. This measure corresponded accurately to the measure made with the hydrometer method.

The results indicate a majority of sand in every sample (60\%) with equal amounts of silt (20\%) and clay $(20 \%),($ Table IV).

TABLE IV

TEXTURAL ANALYSIS OF SOILS FROM TURF-BANKED TERRACES

\begin{tabular}{|cccccc|}
\hline Sample & Location & \% Sand & \% Silt & \% Clay \\
\hline 1 & Maiden Peak & 60 & 20 & 20 \\
\hline 2 & Maiden Peak & 58 & 18 & 24 \\
\hline 3 & Maiden Peak & 60 & 26 & 14 \\
\hline 4 & Maiden Peak & 58 & 20 & 22 \\
\hline 5 & Gray Wolf & 64 & 20 & 16 \\
\hline 6 & Gray Wolf & 68 & 18 & 14 \\
\hline
\end{tabular}

The samples are very consistent, revealing the soils were derived from similar parent rock and that soil development and weathering has been similar. The high proportion of sand reveals that the parent rock is mainly sandstone. The weathering of slate and siltstone have 
contributed slightly as shown by the smaller percentage of silt and clay in the samples.

\section{SOIL FORNATION}

Ice crystals, the most important agent of rock breakdown in cold climates, can best develop pressure in relatively permeable fine-grained rocks having numerous small pore spaces, such as shales, schists, slates, phyllites, and some sandstones (Faber, 1943, p. 1447-1448). Swelling in the clay-rich sedimentary rocks is largely responsible tor a spontaneous break-up known as slaking, in which the shale crumbles into small chips or pencil-like fragments when exposed to the air. These fragments, called phyllite, are frequent on the outcrops of bedrock. Studies in several of the western states have shown that soils derived from granite, quartz, diorite, granodiorite, and certain highquartz sandstones are more erodible than soils derived from basalt, andesite, and gabbro. Thus the higher the quartz content of the parent material, the greater the potential erosion hazard of the resultant soil.

Lobes and terraces have been found on a variety of rock types on other areas, however; and most investigators have felt that rock type is not a major determinant for solifluction on a global scale including. Sigafoos and Hopkins (1952, p. 182), Johnson and Billings (1962, p. 129), and Washburn, (1967, p. 105). 
CHAPTER IX

SOIL MOVEMENT MEASUREMENTS

There are many indications that the turf-banked terraces are presently active. On the risers of terraces the underground stems of the plants extend upslope, indicating that the terminal portions of the stems have dropped down the slope or have been pushed by flowing soil. Chunks of sod have occasionally fallen away from the faces of terrace risers where they approach the vertical and this debris forms miniature talus slopes at the base of the riser. Some terrace risers appear to have burst from upslope water pressure and have spilled soil and rocks onto the terrace tread downslope. Pressure from flowing soils occasionally results in collapsed lobe risers (Figure 22). Johnson and Billings (1962) and Billings and Mark (1961) found similar indications of slow movement. The treads of many terraces are hummocky, indicating that soil is flowing beneath the vegetative layer. These hummocks are incipient lobes and terraces.

Stone stripes which occur in limited areas at both Waiden Peak and Gray Wolf, show indication of needle ice activity, especially in the form of nubbins and sorting. "There is, no doubt, slow, downslope creep of the rock 


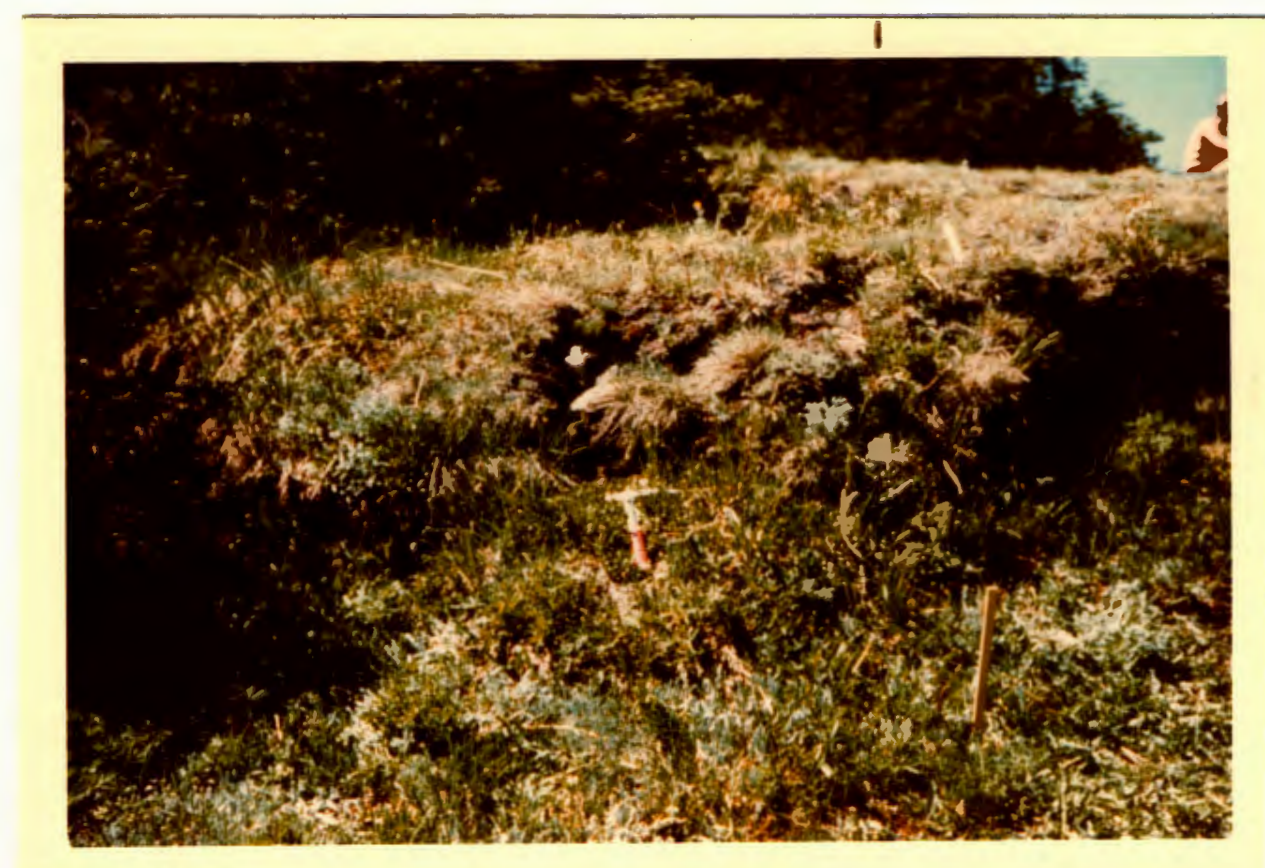

Figure 22. Pressure from flowing soils occasionally results in collapsed lobe risers.

mantle, though little evidence for this can be seen in the disruption of plants", (BIiss, 1966, p. 174).

On the lower portions of the slopes there is indication of an advancing treeline by occasional young trees which have become established above the general forest limit. These young trees have apparently grown during an interval when soil movement was relatively inactive. At the present time, however, many of the trees have bent tree trunks as a result of downslope movement (Figure 23). Also on the upslope side of the tree trunks is a build-up of soil which has flowed downslope and is now banked against the tree. 


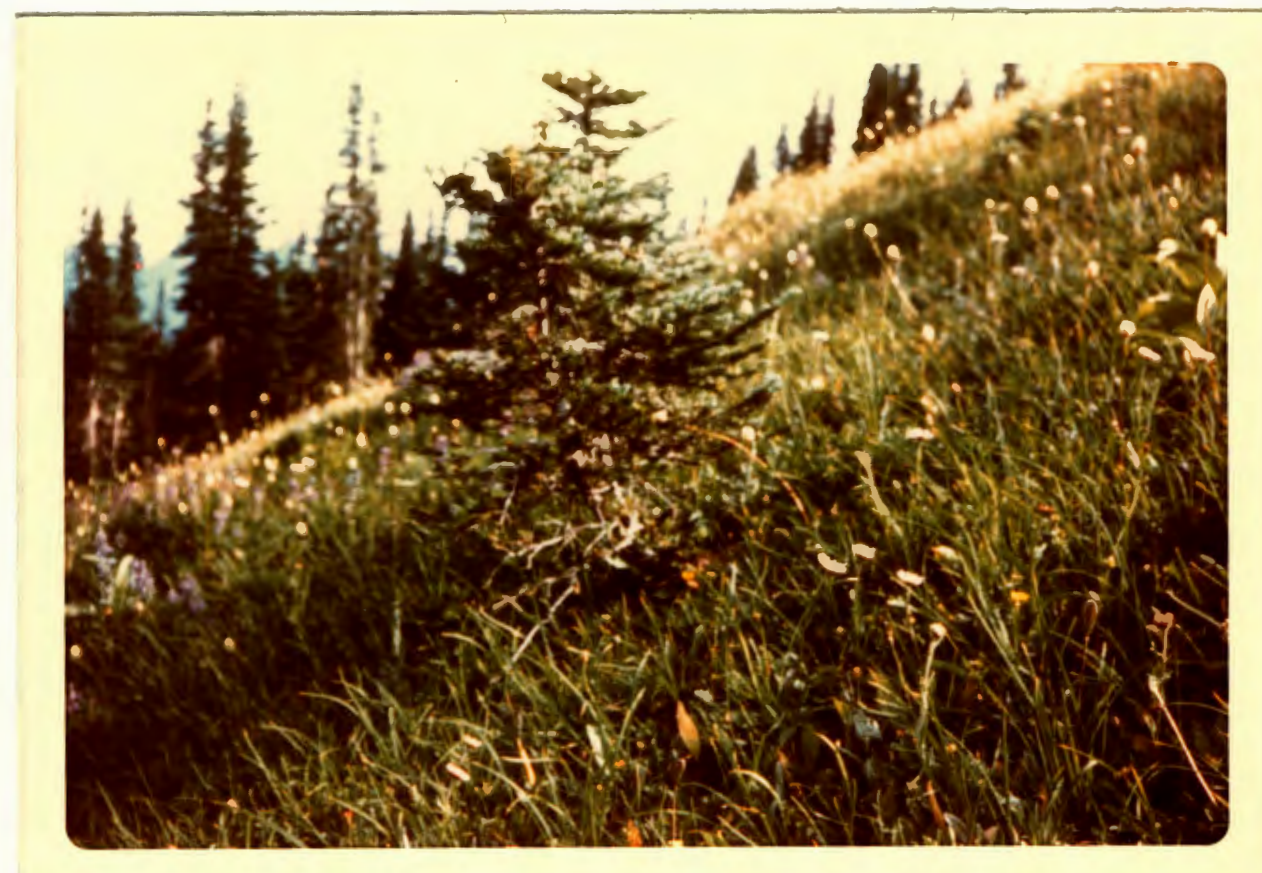

Figure 23. Many of the trees have bent tree trunks as a result of downslope movement.

In order to ascertain the present rate of soil movement within the turf-banked terraces of the Olympic Mountains, measurements were made by painting in situ (in place) rocks. Price and Alexander (1970, p. 136) believe this is the best of the instrument methods for measuring surface movement. With this method, the internal structure of the terraces is in no way disturbed. Measured rocks were in situ so that their subsequent movement indicates soil flow movement. In situ rocks were used where a bedrock reference point was at a reasonably short distance. In places where no close-by bedrock could be used, large, partially buried boulders were used. 
Both Bedrock and in situ rock were marked with a small ' $x$ ' painted with an oil-base red paint. Measurements between rocks were made with a steel tape. The same tape will be used for all measurements. The tape was stretched tauntly and a distance reading was taken at the center of the ' $x$ ' on the in situ rock to the center of the ' $x$ ' on the bedrock.

Measurements were made during the summer of 1975 and will be rechecked during the summer of 1976. 


\section{CHAPTER $\mathrm{X}$}

\section{FACTORS INFLUENCING THE DISTRIBUTION}

\section{AND DEVELOPMENT OF TURF-BANKED TERRACES}

Turf-banked terraces are scarce in the mountains of the Pacific Northwest, but they are well-developed on a few slopes of the Olympic Mountains.

The 0lympics differ from the other mountains of the Pacific Northwest in that their major rock type is sedimentary rather than volcanic or plutonic-metamorphic.

Sedimentary rock has a faster rate of decomposition than basalt or granite, resulting in finer material. In the Olympics, sedimentary rock slopes weather into gently rounded slopes as opposed to the steep, fractured slopes of basalt or granite found throughout most of the Pacific Northwest.

Although it is one of the wettest areas in the United States, the northeast sector of the Olympic Mountains actually has a drier climate than most of the other mountains in the Pacific Northwest. The northeast olympics in the rainshadow of Mount olympus differs from the rest of the olympics in that their climate is much drier and more continental, receiving about $760 \mathrm{~mm}\left(30^{\prime \prime}\right)$ precipitation as opposed to about $3000 \mathrm{~mm}$ (120") on the west side. This dry climate 
and its positive effect on physical weathering is reflected in the presence of four or five rock glaciers in the northeast Olympics. Rock glaciers are usually found only in areas with a dry climate such as Nevada, Colorado, Montana, and to a slight degree on the lee side of the North Cascades of washington. Rock glaciers are not found in most of the other mountains of the Pacific Northwest due to the moister climate and few freeze-thaw cycles in these areas.

Within the Olympic Mountains, turf-banked terraces are also developed only in the extreme northeast section of the region. In this area the slopes become free of snow in late spring while slopes in the other areas of the Olympics are snow covered until middle to late summer. This smaller amount of snow cover allows frequent freezing and thawing of the surface resulting in intensive mechanical breakdown of the sedimentary ridges and the formation of rounded alpine slopes and rock glaciers.- Because of its resistance to weathering and erosion, the ring of basalt of the Crescent Formation to the north and east has comparatively steeper slopes.

Timberline is also higher in the northeast section, where there is less moisture and cloud cover when compared to the rest of the olympics. It reaches an elevation of $1725 \mathrm{~m}$ (5750'). in the east compared to about $1500 \mathrm{~m}$ (4500) 
in the west. This is a reflection of the dryness of the northeast. Snowline is higher as reflected in the lower limit of the alpine glaciers in the northeast and unglaciated slopes exist.above treeline.

Turf-banked terraces are developed primarily on the north-facing slopes where the topography provides protection from southwesterly winds and solar radiation and allows snowbanks to remain late into spring. Terraces are developed on the gentle sedimentary slopes where the soil texture retains moisture but not on the steeper basaltic slopes which have little soil development and little moisture retention. In the olympics the turf-banked terraces are generally restricted to slopes of $12^{\circ}$ to $24^{\circ}$. As a result of the late meltwater, alpine vegetation covers almost $90 \%$ of the gentle, north-facing slopes. The south-facing slopes are dry and almost barren by comparison. The alpine vegetation on north-facing slopes consists of sedges, grasses, and matted, woody plants which have fine and extensive root systems. These roots bind the soil and give the slopes a greater degree of stability than on the south-facing slopes. The vegetation cover, once established, also insulates the soil, preventing dessication. The organic material within the soils, especially the roots, increases the water-holding capacity of the sandy loam soils.

Nicroenvironments are formed by the terraces. The riser provides protection from winds and radiation and a 
snowbank is able to last late into spring immediately below the riser. This protected and moist microenvironment allows the growth of less-hardy and less-drought resistant plant species. The riser front also provides shelter for burrowing animals. Less protection is provided downslope from the riser. Many terraces have developed sorted ground features on their treads as enough moisture is available for intense frost creep and frost stirring. The part of the tread farthest from late-lying snowbanks and meltwater, is the harshest envirament on the terraces. This area is exposed to dessicating wind and develops a plant cover which is hardy and drought-resistant.

The turf-banked terraces of the Olympic Mountains are smaller in size than those found in other areas, such as the Rocky Mountains or Alaska, indicating a lower level of activity.

As the north-facing slopes become. relatively free of snow in spring, low temperatures and lack of insulation by snow results in a frozen soil surface. Then, as latelying snowbanks begin to melt, the water is unable to percolate down through the frozen soil, and the upper surface layer of the surface become very moist. Water is retained in the sandy loam soils by silt and clay, which together compose $40 \%$ of the soil, and by organic material which binds the soil as well as prevents dessication. The soil becomes saturated, and, under the influence of gravity, begins to 
move downslope. The movement is not as fast as a mudflow nor as slow as creep, but is a viscous flow, partially restrained by the vegetation. The flow is most rapid in the center of the terrace where there is least friction from the vegetation or the frozen soil layer below. This movement gives the terraces their typical lobate appearance. Evidence from the lobe excavations shows that the soil movement is possibly of two types. The first type consists of the flowing soil "rolling over" and burying existing vegetation. The second type of movement is soil flowing beneath the vegetative layer without actually covering or breaking the vegetative cover. The shape of the lobes as well as the vegetation communities show that the movement often is not directly downslope but rather in the direction of snow deposition, towards the lee side of the terrace. Again, moisture is the prime controlling factor for movement. The saturated soil continues to flow until halted by restraining vegetation or perhaps by a large rock, or until the slope decreases and the force of gravity is lessened. As the soil builds up, the terrace riser is formed.

While the terrace is temporarily halted, the ratchetlike downslope movement of frost creep becomes dominant. During a freeze, moisture is drawn to the surface through capillary action and needle ice is created. This forces the 
surface material outward which upon thawing, the ice crystals drop their load. On level ground frost creep results in patterned ground features, on slopes it contributes to downslope movement. This downslope creep facilitates the actual movement of the terraces as well as contribates to the general instability on the slope.

Radiocarbon dates from other areas suggest conditions for the northern hemisphere as a whole were most favorable for terrace formation between 2500 and 3000 years B.P. I assume the terraces of the Olympics to have formed at this same time. The date indicates that the present phase of terrace development may have begun with the advent of neo-glaciation and the close of the hypsithermal (Denton and Stuiver, 1966; and Deevey and Flint, 1957, in Price, 1974, p. 438).

Although data on the rate of movement of the turfbanked terraces in the Olympics have not yet been obtained, hummocky treads, bulging risers, fresh scars of collapsed risers, loose stones with no lichen growth on lobe treads, and continued needle ice activity indicate a fairly intense level of activity at present. On the other hand, the decomposed condition of the buried organic material found indicates that the soil movement has taken place over a long period of time.

Andersson (1906, p. 101), suggests that the structured soils he found were formed in the past when the climate was 
more severe, with heavy snowfalls in winter and active snowmelting in summer. Antevs (1932, p. 61) states that "Geologically speaking, these are short-lived phenomenon. Those now in existence may all be modern, although terraces perhaps have occurred on the same slopes for thousands of years." It is suggested by Crampton and Taylor (1967, p. 34) that the solifluction terraces described in South and Central Wales formed in a late. WUrm or Post WUlm periglacial environment. Price (1970, p. 221) found, in the Ruby Range, "Radiocarbon dating of the buried organic layers from the rear of an excavated lobe on the southeast slope yields dates of $2,490 \pm 150$ years and $2,630 \pm 100$ years B.P.". Benedict, 1975, indicates that the majority of authors have found terraces to be products of former conditions. "Perhaps this is a result of our tendency to choose welldeveloped deposits for .stratigraphic studies, and to ignore slight bulges in the turf that mey represent incipient lobes or terraces. There is no compelling reason why the features should not be forming today, although perhaps at much slower rates than during the past" (Benedict, 1976, p. 66). Solifluction terraces, during the process of moving downslope, erode and cover up surface irregularities. Ridges become less steep and slopes become rounded. There is no doubt that solifluction and frost-creep are major agents of denudation in the alpine zone of the northeast Olympic Mountains. 


\section{CHAPTER XI}

\section{CONCLUSION}

Well-developed turf-banked terraces are found in the Olympic Mountains of Washington, but not elsewhere in the Coast Range, nor in the Cascades, the Blue Mountains, or the Steens of the Pacific Northwest. Turf-banked terraces occur in the Olympics, in the northeast section, where the climate is relatively dry and there are numerous freeze-thaw cycles, not where excessive precipitation provides a mild, moist climate. Terraces develop in the Olympics only on soil derived from sedimentary rock which has a high rate of decomposition and breaks into fine material, not on the coarse soils formed from basalt or granite with a slow rate of decomposition.

Within their areas of occurrance, terraces develop on north-facing slopes which are protected from strong southwesterly winds and where soil is present. Terraces are found on the gentle, rounded alpine slopes, not steeper than $24^{\circ}$ nor flatter than $12^{\circ}$, where only occasional outcrops of bedrock are found. These rounded ridges have apparently not been glaciated but rather have undergone cryoplanation over a long period of time. Terraces do not occur on south-facing slopes which are steep and 
have little soil development. Nor are they found on the steep, Jagged cirque heads, nor on the active cirque walls. Terraces are well-developed immediately below latelying snowbanks which provide moisture that saturates the soil when melting. Alpine vegetation with fine, thicklymatted roots covers the moist, north-facing slopes, binding the soil, and the organic material assists the sandy loam in retaining water. Terraces do not develop in the olympics on unvegetated slopes.

Animals affect the terraces causing downslope movement where the soil is saturated. Where grazing removes vegetation frost action is promoted. Hikers crossing the terraces crush and uproot flowers and stems, but the concentration of traffic on trails is better than dispersed use since it limits the damage.

Movement of soil takes place during spring thaws when a frozen layer in the soil prohibits downward percolation of meltwater. Higher velocities in the center of the lobe results in the typical lobate appearance of the terraces.

It is hypothesized that terrace development began between 2500 and 3000 years B.P. The terraces appear active today. Hummocky treads, bulging risers, collapsed lobes give evidence of movement.

The occurrence of the terraces in the Olympic Mountains results from the complex interaction of many environmental 
factors, the most important being climate, slope gradient and slope orientation, and soil type. The understanding of these factors is valuable not only to the geomorphologist and ecologist but to anyone who understands and respects the hardy delicateness of an alpine ecosystem. 


\section{A SELECTED BIBLIOGRAPHY}

Andersson, J. G., 1906, "Solifluction, A Component of Subaerial Denudation, Journal of Geology, Vol. 14, pp. 91-112.

Antevs, E., 1932, Alpine Zone of Mt. Washington, Merrill and Webber Company, Maine.

Bell, K. L. and L. C. Bliss, 1973, "Alpine Disturbance Studies: Olympic National Park, USA," Biological Conservation, Vol. 5, No. 1, pp. 25-32.

Benedict, J. B., 1970, "Downslope Soil Movement in a Colorado Alpine Region: Rates, processes and Climatic Significance," Arctic and Alpine Research, Vol. 2, pp. 165-226.

Benedict, J. B., 1976, "Frost Creep and Gelifluction Features: A Review," Quaternary Research, . Vol. 6, pp. 55-76.

Billings, W. D. and A. F. Mark, 1961, "Interactions between Alpine Tundra Vegetation and Patterned Ground in the Mountains of Southern New Zealand," Ecology, Vol. 42 , pp. $18-31$.

Bliss, L. C., 1966, "Alpine Community Pattern in Relation to Environmental Parameters," Essays in Plant Geography and Ecology, Nova Scotia Museum, Nova Scotia.

Bliss, L. C. and R. Fonda, 1969, "Forest Vegetation of the Montane and Subalpine Zones, Olympic Mountains, Washington," Ecological Monographs, Vol. 39, pp. 271-301 .

Bouyoucos, G. J., 1936, "Directions for Making Mechanical Analysis of Soils by the Hydrometer Method," Soil Science, Vol. 42, pp. 225-229.

Cailleux, A., 1950, "Rate of Movement of Surface Debris in Solifluction Processes, Journal of Glaciology, Vol. 1, p. 394 .

Crampton, C. B. and F. A. Taylor, 1967, "Solifluction Terraces in South Wales" Biuletyn Peryglacjalny, Vol. 16, pp. $15-36$. 
Crande11, D. R., 1965, "The Glacial History of Western Washington and Oregon," The Quaternary of the United States, pp. 34-353. .

Curtis, J. T. and R. P. NicIntosh, 1951, "The Upland Forest Continuum in the Prairie-Forest Border Region of Wisconsin," Ecology, Vol. 32, pp. 476-496.

Deevey, E. S. and R. F. Flint, 1957, "Post-Glacial Hypsithermal interval," Science, Vol. 125, No. 3236, pp. 182-184.

Denton, G. H. and M. Stuiver, 1966, "Neoglacial Chronology, Northeastern St. Elias Mountains, Canada," American Journal of Sciences, Vol. 264, pp. 597-598.

Drew, J. V. and R. E. Shanks, 1965, "Landscape Relationships of Soils and Vegetation in the Forest-Tundra ecotone, Upper Firth River Valley, Alaska-Canada," Ecological Monographs, Vol. 35, No. 3, pp. 285-306.

Drury, W. H., 1962, 'Patterned Ground and Vegetation on Southern Bylet Island, Northwest Territories, Canada," Contributed by Gray Herbarium, No. 190, Harvard University.

Dutkiewicz, L., 1961, "Congelifluction Lobes on the Southern Hornsund Coast in Spitsbergen," Biuletyn Peryglacjalny, Vol. 10, pp. 285-289.

Hubley, R. C., 1956, "Glaciers of the Washington Cascade and Olympic Mountains," Journal of Glaciology, Vol. 2, pp. 669-674.

Jahn, A., 1960, "Some Remarks on Evolution of Slopes on Spitsbergen," Zeitschrift fur Geomorphologie, Vol. I, pp. 49-58.

Johnson, P. L. and W. D. Billings, 1962, "The Alpine Vegetation of the Beartooth Plateau in Relation to Cryopedogenic Processes and Patterns," Ecological Monographs, Vol. 32, pp. 105-135.

Jones, G. N., 1936, A Botanical Survey of the Olympic Peninsula, Washington, The Uriversity of Washington Press, Seattle, Washington.

Kuramoto, R. T. and L. C. Bliss, 1970, "Ecology of Subalpine Meadows in the Olympic Mountains, Washington", Ecological Monographs, Vol. 40, pp. 317-347. 
Long, W. A., 1975, "Salmon Springs and Vashon Continental Ice in the Olympic Mountains and the Relation of Vashon Continental to Fraser Olympic Ice," U.S. Forest Service Employee Report.

Lundquist, G., 1949, "The Orientation of the block material in Certain Species of Flow Earth," Geografiska Annaler, Vol. 31, pp. 335-347.

McKee, B., 1972, Cascadia, McGraw-Hili, Inc., San Francisco.

Officials of the National Oceanic and Atmospheric

Administration, U.S. Department of Commerce, 1974, Climates of the States, Water Information Center, Inc., New York.

Porter, S. C., 1964, "Composite Pleistocene Snow Line of Olympic Mountains and Cascade Range, Washington," Geological Society of America, Bulletin, Vol. 75, pp. 477-482.

Price, L. W., 1970, Norphology and Ecology of Solifluction Lobe Development--Ruby Range, Yukon Territory, Unpublished Ph.D. dissertation, University of Illinois, Urbana, Illinois.

Price, L. W., 197la, "Vegetation, Microtopography, and Depth of Active Layer on Different Exposures in Subarctic Alpine Tundra," Ecology, Vol. 52, No. 4, pp. 683-647.

Price, L. W., 1971b, "Geomorphic effect of the Arctic Ground Squirrel in an Alpine Environment," Geografiska Annaler, Vol. 53A, pp. 100-106.

Price, L. W., 1972, The Periglacial Environment, Permafrost, and Man, Association of American Geographers, Commission of College Geography, Resource Paper No. 14, Washington, D. C.

Price, L. W., 1974, "The Developmental Cycle of Solifluction Lobes," Annals of the Association of American Geographers, Vo1. 64, No. 3 pp. 430-438.

Price, L. W. and C. S. Alexander, 1971, "Methods of Measuring Mass Wasting: Review and Critique," Proceedings of the Association of American Geographers, Vol. 3, pp. 135I39.

Rudberg, S., 1958, "Some Observations Concerning Mass Movement on Slopes in Sweden," Geolog. Foren. Forhandlingor, Vol. 80, No. 8, pp. 114-125. 
Seidenfaden, G., 1931, "Moving soil and vegetation of East Greenland," Miedd. om Gronland, Vol. 87, No. 2, pp. 1-2l.

Sigafoos, R. S., 1951, "Soil Instability in Tundra Vegetation," Ohio Journal Science, Vol. 51, pp. 281-298.

Sigafoos, R. S. and D. M. Hopkins, 1952, "Soil Instability on Slopes in Regions of Perennially-Frozen Ground," Frost Action in Soils, A Symposium, Highway Research Board, Special Report No. 2., Washington, D.C., pp. $176-191$.

Taber, S., 1943, "Perennially Frozen Ground in Alaska: Its Origin and History," Bulletin Geological Society America, Vol. 54, pp. $1433-1548$.

Tabor, R. W., 1975, Guide to the Geology of the Olympic National Park, The University of Washington Press, Seattle.

Troll, C., 1958, Structure Soils, Solifluction, and Frost Climates of the Earth, Translation 43, U.S. Army Snow Ice and Permafroot Research Establishment, Corps of Engineers, Wilmette, Illinois.

Washburn, A. L., 1947, "Reconnaissance Geology of Portions of Victoria Island and Adjacent Regions, Arctic Canada," American Geological Society Memorandum 22.

Washburn, A. L., 1956, "Classification of Patterned Ground and a Review of Suggested Origins," Geological Society America Bulletin, Vol. 67, pp. 823-866.

Washburn, A. L., 1967, "Instrumental Observations of MassWasting in the Nesters Vig District, Northeast Greenland," Meddelelser om Gronland, Vol. 166, No. 4, pp. $1-30$.

Washburn, A. L., 1973, Periglacial Processes and Environments, Edward Arnold, London.

Williams, P. J., 1957, "Some Investigations into Solifluction Features in Norway," Geographical Journal, Vol. 73 pp. $42-58$.

Wilson, J. W., 1952, "Vegetation Patterns Associated with Soil Movement on Jan Mayen Island," Journal of Ecology, Vol. 40, p. 249. 